\title{
COASTAL DUNES OF THE BALTIC SEA SHORES: A REVIEW
}

\author{
Tomasz Arkadiusz Łabuz ${ }^{1}$, Ralf Grunewald ${ }^{2}$, Valentina Bobykina $^{3}$, \\ Boris Chubarenko ${ }^{3}$, Algimantas Česnulevičius ${ }^{4}$, Artūras Bautrénas ${ }^{4}$, \\ Regina MORKŪNAITE் ${ }^{5}$, HANNes TÕNISSON ${ }^{6}$ \\ ${ }^{1}$ Faculty of Geosciences, University of Szczecin, Szczecin, Poland \\ ${ }^{2}$ Federal Agency for Nature Conservation, Isle of Vilm, Putbus, Germany \\ ${ }^{3}$ Shirshov Institute of Oceanology of Russian Academy of Sciences, Moscow, Russia \\ ${ }^{4}$ Faculty of Chemistry and Geosciences, Vilnius University, Vilnius, Lithuania \\ ${ }^{5}$ Institute of Geology and Geography, Nature Research Centre, Vilnius, Lithuania \\ ${ }^{6}$ Institute of Ecology, Tallinn University, Tallinn, Estonia
}

Manuscript received: December 17, 2017

Revised version: January 18, 2018

Łabuz T.A., Grunewald R., Bobykina V., Chubarenko B., Česnulevičíus A., Bautrénas A., Morkünaitė R., Tõnisson H., 2018. Coastal dunes of the Baltic Sea shores: a review. Quaestiones Geographicae 37(1), Bogucki Wydawnictwo Naukowe, Poznań, pp. 47-71. 10 figs, 2 tables.

AвSTRAст: The article summarises results of studies conducted along the Baltic Sea sandy coasts by scientists involved in coastal dune research, and presents an attempt to describe the types and distribution of dune coasts. The Baltic Sea coasts feature lower and higher foredunes. The lowland behind the coastal dune belt is covered by wandering or stabilised inland dunes - transgressive forms, mainly parabolic or barchans. The source of sediment for dune development includes fluvioglacial sands from eroded coasts, river-discharged sand, and older eroded dunes. Due to the ongoing erosion and coastal retreat, many dunes have been eroded, and some are withdrawing onto the adjacent land. There are visible differences between the south-eastern, western, and northern parts of the Baltic Sea coast with respect to dune development. The entire southern and eastern coast abounds in sand, so the coastal dunes are large, formerly or currently wandering formations. The only shifting dunes are found at the Polish and the Russian-Lithuanian coasts on the Łebsko Lake Sandbar as well as on the Vistula and Curonian Spits. The very diverse shoreline of the south-western coast experiences a scarcity of larger sandy formations. Substantial parts of the Baltic Sea sandy coasts have been eroded or transformed by humans. The northern part of the Baltic Sea coast features mainly narrow and low sandy coasts (e.g. in Estonia). Further north, sandy dunes are virtually absent.

KEY WORDS: coastal dunes, dune relief, barrier types, dune distribution, Baltic Sea coast

Corresponding author: Tomasz A. Łabuz, tomasz.labuz@usz.edu.pl

\section{Introduction}

A coastal dune shore is one of the most dynamic marine environments, affected by climate-related natural factors such as storm surges, water level fluctuations, and winds as well as the presence of vegetation. Currents and wave action are responsible for the formation of accumulative features such as sand barriers, beaches, and spits. Coastal dunes develop mainly on low-lying shores and on sandy barriers that have been formed, and shaped by the sea, in the past or more recently.

In the light of increasing and diverse threats to coastal environments, it is important to reflect on how the present-day dune environment has 
been, and is developing, under natural and human pressures. Despite their high ecological value, many coastal dunes were heavily degraded during the last century as a result of exploitation of their natural resources, demographic expansion, and industrial growth. Human impact, including tourism, plays an important role in shaping dune relief and in changing dune-associated habitats, which ultimately leads to dune destruction and disappearance of the invaluable natural environment.

The Baltic coasts are susceptible to wind and wave impacts, including storm surges, destructive forces which cause shore erosion the extent of which cannot be predicted with any certainty. Moreover, an identical weather factor may produce a different effect, depending on the coastal exposure. Examples are provided by storm surges in 1995, 2007, 2009, 2012, 2015 and 2017 each of which impacted a different stretch of the southern Baltic coast or storm surges in 1999, 2005, 2013, and 2015 which mainly eroded the eastern coast of Lithuania and a stretch extending from Latvia to Estonia. Moreover, as the wind changes its direction, a different part of the coast may be affected.

The southern Baltic coast tends to be eroded by surges produced by the north-westerly winds, the eastern coast being eroded mainly by surges generated by the westerlies. The northern part of the coast does not experience such strong effects. In the past, a good protection against storm surges was provided by ice cover. At present, the ice cover, even in the northern part of the Baltic Sea, is diminishing on account of the shortening of the ice season, shrinking of the ice cover range, and thinning of the ice layer. This induces erosion on those parts of the coast that have so far been more resistant.

This paper describes the most important sandy coasts along the Baltic Sea with the aim of describing the present morphological features and relief of those coasts, affected by the changing climate and an increasing demand for human use.

This work is a collaborative project of scientists from the Baltic Sea countries who focus on coastal processes and geomorphology of sandy shores. All photographs were provided by the authors. Profiles were drawn using topographical maps and field measurements (Łabuz 2017).

\section{Types of sandy-dune barriers along the Baltic coast}

Coastal barriers - sandbars, formed as sand belts or spits - develop on low-lying shores covered by marine sands. They adjoin terrains of fluvial, limnic or organic origin (Sweden, Poland, Latvia) and separate bays, coastal lagoons, straits, and lakes from the open sea (Germany, Poland, Russia, Lithuania). There are also coastal barriers that have developed on uplifted low shores, in river mouths or behind rocky promontories (Estonia, Finland, Denmark). Some of them formed from single islands situated close to the mainland (Denmark, Germany). Certain barriers are wide and feature a complex of coastal and inland-shifting dunes, e.g. the Curonian Spit in Lithuania and Russia; others are very narrow, e.g. the Jamno or the Bukowo lake sandbars in the central part of the Polish coast. The abundance of sand left after deglaciation allowed a number of large and small barriers to emerge at the Baltic coast, the longest barriers being found at the southern coast (Fig. 1). The northern part of the Baltic coast lacks any longer sandy coasts. The sandy-dune coasts of the Baltic Sea can be assigned to several types (Table 1 ).

\section{Major dune formations}

The barrier surface is formed mainly by low-lying areas, up to 2-4 $\mathrm{m}$ above the sea level (a.s.l.) with one or several coastal dunes between the hinterland and the beach (Table 2 - presents main coastal forms distribution). Some barriers feature older and higher dunes representing transverse, parabolic or barchan-type formations (Table 2, Fig. 10). The highest such forms are: Vecekrugo Dune (67 m), Efa Dune (62-64 m), Parnidis Dune (52-56 m) on Curonian Spit, Camel Hump (47 m) on Vistula Spit, Czołpińska (56 m) and Łącka Dune (40-42 m) on Łebsko Lake Sandbar, Pūsēnu Hill $(37 \mathrm{~m})$ and Tornimägi Hill $(35 \mathrm{~m})$, both on Latvian and Estonian East Baltic coast. The remnants of such high forms can be found on German coast - Höhe Dune (19 m) on Darss peninsula.

Seaward, the fore dune faces a beach which rises up to $2 \mathrm{~m}$ a.s.l. at an accumulative and erosive coast, respectively. On coast with accumulative 


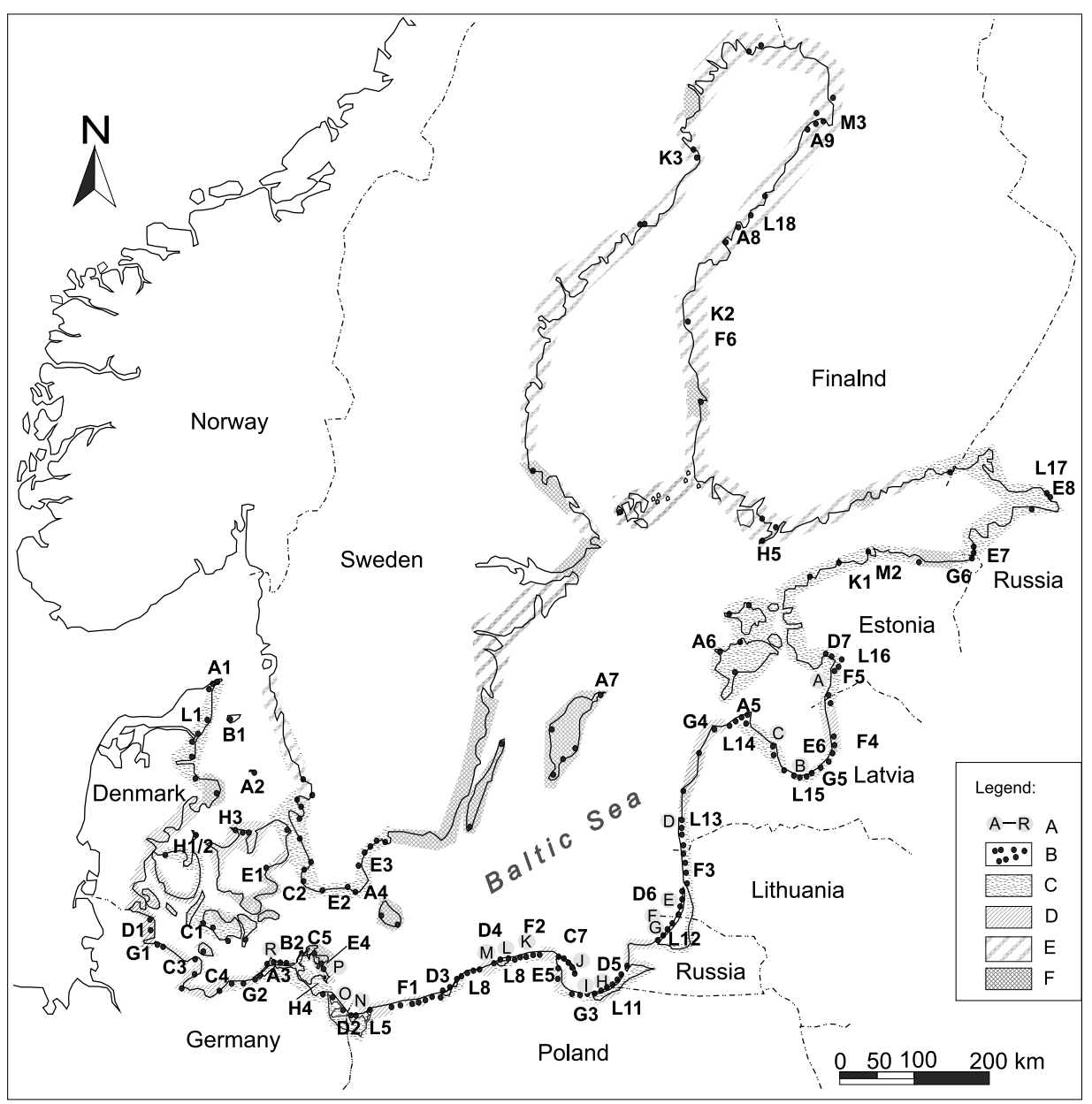

Fig. 1. Location of varied sandy and other coasts around Baltic Sea (based on Łabuz 2015b); letters and digits refer to sandy coast type, see Table 1.

A - transgressive dune fields, examples, see fig 10, B - sandy barriers and dune coasts, C -low organic coast: meadows and wetlands, D - soft moraine cliffs, E - skerries, F - rocky cliffs.

tendencies beach is covered by sand hillocks and reach up to $3.5 \mathrm{~m}$ a.s.l. The beach descends to a shallow shoreface with one or several sandy shoals. Its number refers to coast progradation. The more shoals, the huger accumulative tendencies can be observe.

The machair type coast, known from Northern Ireland, may be found on sheltered coasts with surface sands densely covered by vegetation, mostly reeds. Outside Finland, this type of the coast can be seen in the Gulf of Gdańsk and its Puck Bay in Poland as well as at several places of the Estonian coast.

A typical coastal dune profile features a dune ridge (or ridges) generally rising to 3-12 $\mathrm{m}$ above the mean sea level (a.s.l). The landward side of a sandy belt may be covered by swampy lowlands, coastal lakes or bays and lagoons (most developed foredune systems are presented in Table
2). The lowlands are mainly organic in origin, formed by fluvial, limnic or wetlands deposits. Under favourable conditions of material accumulation, the lowland behind the coastal dune belt features wandering or stabilised inland dunes, mainly parabolic or barchans (e.g. the Curonian Spit, the Łebsko Lake Sandbar). Usually, the coast is composed of coastal foredune formations such as a ridge or separate hillocks. The coast in areas with prevalent erosion is built by eroded older dune formations shaped hundreds or thousands years ago, migrating on land. To sum up, the sandy coast may feature:

- former or recent coastal sand formation ridges (foredunes),

- sandy dunes or sand bodies filling depressions separating convex dune formations.

The very small Danish Anholt Island in the middle of the Kattegat (at the entrance to the Baltic 
Table 1. Classification of sandy coast sandbars of the Baltic Sea (Łabuz 2017, unpublished).

\begin{tabular}{|c|c|c|c|}
\hline No. & Coast type & Definition & Examples (see fig. 1) \\
\hline \multirow[t]{9}{*}{ A } & \multirow{9}{*}{$\begin{array}{l}\text { Cuspate fore- } \\
\text { land }\end{array}$} & \multirow{9}{*}{$\begin{array}{l}\text { Cuspate forelands (A) - kind of sandy promontory in } \\
\text { shape of arch or promontory entering the sea. Three } \\
\text { sides are open to sea, covered by small foredunes. }\end{array}$} & Skagen (A1) \\
\hline & & & Anholt (A2) \\
\hline & & & Darss (A3) \\
\hline & & & Sandhamaren (A4) \\
\hline & & & Kolka (A5) \\
\hline & & & Hairlaid, Cape Kiipsaare (A6) \\
\hline & & & Faro / Gotland (A7) \\
\hline & & & Vattaja (A8) \\
\hline & & & Tauvo (A9) \\
\hline \multirow[t]{3}{*}{ B } & \multirow[t]{3}{*}{ Barrier islands } & \multirow{3}{*}{$\begin{array}{l}\text { Barrier islands (B) - separate sandy bodies surrounded } \\
\text { by sea, that are build by currents and waves as lonely } \\
\text { forms of different length and width. The more width } \\
\text { island, the larger dunes has. }\end{array}$} & Stokken (B1) \\
\hline & & & $\begin{array}{l}\text { Small islands of South Denmark - } \\
\text { Fionia, Lolland (B2) }\end{array}$ \\
\hline & & & Hiddensee (B3) \\
\hline \multirow[t]{8}{*}{ C } & \multirow[t]{8}{*}{ Spits } & \multirow{8}{*}{$\begin{array}{l}\text { Spits (C) - separate sandy strips of different length, } \\
\text { that have been built due to prevailing sand transport } \\
\text { and accumulation in axis of coastline with its abrupt } \\
\text { change. From one side adjacent to the land, shielding } \\
\text { lagoons and bays from open sea. }\end{array}$} & $\begin{array}{l}\text { Albuen, Hyllekrog on South Lol- } \\
\text { land Island (C1) }\end{array}$ \\
\hline & & & Falsterbo (C2) \\
\hline & & & Heiligenhafen (C3) \\
\hline & & & Durchlass (C4) \\
\hline & & & Bug (C5) \\
\hline & & & Usedom North (C6) \\
\hline & & & Hel, Rewa (C7) \\
\hline & & & Vihaspauha (C8) \\
\hline \multirow[t]{7}{*}{$\mathrm{D}$} & \multirow[t]{7}{*}{ Spit barriers } & \multirow{7}{*}{$\begin{array}{l}\text { Spit barriers (D) - separate spits, one or two or jointed } \\
\text { barrier islands which due to lateral increase formed } \\
\text { barrier, separating water body or swamp/wetland, } \\
\text { jointed by channel or mouth with the proper sea basin. }\end{array}$} & Schleimundung (D1) \\
\hline & & & $\begin{array}{l}\text { Swina Gate on Wolin and Usedom } \\
\text { islands (D2) }\end{array}$ \\
\hline & & & Jamno, Bukowo lakes (D3) \\
\hline & & & Gardno-Łebsko-Sarbsko lakes (D4) \\
\hline & & & Vistula (D5) \\
\hline & & & Curonian (D6) \\
\hline & & & Pärnu river mouth (D7) \\
\hline \multirow[t]{8}{*}{$\mathrm{E}$} & \multirow[t]{8}{*}{ Bay barriers } & \multirow{8}{*}{$\begin{array}{l}\text { Bay filling barriers }(\mathrm{E}) \text { - shallow, concave bays, that } \\
\text { are filled by sandy sediment and covered by longitudi- } \\
\text { nal ridges corresponding to phases of land prograda- } \\
\text { tion in such coast protected against waves. Developed } \\
\text { due to sand transport from adjacent eroded cliffs. }\end{array}$} & Koga Bay (E1) \\
\hline & & & Ystad Bay (E2) \\
\hline & & & Yngsjö Bay (E3) \\
\hline & & & $\begin{array}{l}\text { Rügen Island: Schaabe, Schmale } \\
\text { Heide, Baabe, Gohren (E4) }\end{array}$ \\
\hline & & & Gulf of Gdańsk: Sopot-Gdańsk (E5) \\
\hline & & & Jurmala, Gulf of Riga (E6) \\
\hline & & & Narva Bay (E7) \\
\hline & & & Sestrorecks, Finland Bay (E8) \\
\hline \multirow[t]{6}{*}{$\mathrm{F}$} & \multirow[t]{6}{*}{$\begin{array}{l}\text { Welded barriers } \\
\text { of open coast }\end{array}$} & \multirow{6}{*}{$\begin{array}{l}\text { Welded barriers on open coast }(\mathrm{F}) \text { - jointed to the } \\
\text { land of different origin, developed as a accumulation } \\
\text { aligning the rough coastline, sometimes with channel } \\
\text { or river outlet. }\end{array}$} & $\begin{array}{l}\text { West Pomerania: Mrzeżyno, Dźwi- } \\
\text { rzyno area (F1) }\end{array}$ \\
\hline & & & $\begin{array}{l}\text { East Pomerania with Kashubian } \\
\text { and Karwia barrier (F2) }\end{array}$ \\
\hline & & & $\begin{array}{l}\text { Lithuania-Latvia coast (F3): Klai- } \\
\text { peda- Palanga-Sventoji, Pape-Jur- } \\
\text { malciems-Bernati, Liepaja-Skede, } \\
\text { Ziemupe-Pavilosta, Sarnate-Vent- } \\
\text { spils-Irbe river }\end{array}$ \\
\hline & & & East Latvian Gulf of Riga (F4) \\
\hline & & & Rannametsa near Pärnu (F5) \\
\hline & & & Vattaja coast, Lohtaja (F6) \\
\hline
\end{tabular}


Table 1 - cont.

\begin{tabular}{|c|c|c|c|}
\hline \multicolumn{4}{|c|}{ Table 1 - cont. } \\
\hline No. & Coast type & Definition & Examples (see fig. 1) \\
\hline \multirow[t]{6}{*}{ G } & \multirow[t]{6}{*}{ Delta spits } & \multirow{6}{*}{$\begin{array}{l}\text { River deltas }(\mathrm{G}) \text { - prograding delta fans, covered } \\
\text { by organic and sandy deposits, that fills the bays or } \\
\text { creating concave cones, sometimes with embryo spits. } \\
\text { Sometimes it is just part of larger spit. }\end{array}$} & Trave (G1) \\
\hline & & & Warnow (G2) \\
\hline & & & Vistula (G3) \\
\hline & & & Windawa (G4) \\
\hline & & & Daugava (G5) \\
\hline & & & Narva (G6) \\
\hline \multirow[t]{5}{*}{$\mathrm{H}$} & \multirow{5}{*}{$\begin{array}{l}\text { Tombolo sand- } \\
\text { bars }\end{array}$} & \multirow{5}{*}{$\begin{array}{l}\text { Tombolo sandbar }(\mathrm{H}) \text { - single, narrow strip of sand } \\
\text { connecting two previous land areas: two islands or } \\
\text { island and larger land. Developed as sand is settled } \\
\text { in narrow corridor between land obstacles. On Baltic } \\
\text { coast also developed on uplifting rocky basement. }\end{array}$} & Samso (H1) \\
\hline & & & Aebelo - Odense (H2) \\
\hline & & & Sjaellands Odde (H3) \\
\hline & & & Island Vlim (H4) \\
\hline & & & Hanko (H5) \\
\hline \multirow[t]{3}{*}{ K } & \multirow[t]{3}{*}{$\begin{array}{l}\text { Pocket bay } \\
\text { barriers }\end{array}$} & \multirow[t]{3}{*}{$\begin{array}{l}\text { Pocket bay barriers }(\mathrm{K}) \text { - narrow, low and flat sandy } \\
\text { shores, that are hidden in slowly emerging bays, often } \\
\text { with small, sand discharging rivers. }\end{array}$} & $\begin{array}{l}\text { Estonia coast (K1): Tallinn beaches, } \\
\text { Ihasalu beach, Kloogaranna, Vää- } \\
\text { na-Jõesuu, Pedaspea, Kiiu-Aabla }\end{array}$ \\
\hline & & & Finland coast (K2): Kalajoki beach \\
\hline & & & $\begin{array}{l}\text { Sweden coast (K3): Storsand } \\
\text { (Lovanger) }\end{array}$ \\
\hline
\end{tabular}

Table 2. List of main sandy forms at sandbars along the Baltic Sea coast (Łabuz 2017, unpublished).

\begin{tabular}{|c|c|c|c|}
\hline No. & Dune type & Definition & Examples (see fig. 1, 10) \\
\hline \multirow[t]{18}{*}{$\mathrm{L}$} & \multirow{18}{*}{$\begin{array}{l}\text { Inland coastal } \\
\text { sand bodies }\end{array}$} & \multirow{18}{*}{$\begin{array}{l}\text { Shifting or stabilized inland coastal sand bodies (L) - } \\
\text { large dune areas of permanent sand load in the past } \\
\text { and accumulation as different large dunes: as barchans, } \\
\text { parbolic or transverse forms, that are entering foreign } \\
\text { origin basement (older dunes, organic, moraine or rock } \\
\text { structures). Mainly located } 0.2 \text { to } 2 \mathrm{~km} \text { from the coast. } \\
\text { The shape of dunes depend on coast exposition for } \\
\text { prevailing westerly winds: on the south coast barchans } \\
\text { and parobolic are often, on the east coast transverse are } \\
\text { often. On the erosive coast these structures are building } \\
\text { the shore and are partially eroded. }\end{array}$} & Skagen promontory (L1) \\
\hline & & & Darss promontory (L2) \\
\hline & & & Schmale Heide Sandbar (L3) \\
\hline & & & North of Usedom (L4) \\
\hline & & & Swina Gate Sandbar (L5) \\
\hline & & & Ridge near Ustronie Morskie (L6) \\
\hline & & & Ridge West from Kołobrzeg (L7) \\
\hline & & & Ustka (L8) \\
\hline & & & $\begin{array}{l}\text { Gardno-Łebsko lakes, Kashubian } \\
\text { Sandbar (L9) }\end{array}$ \\
\hline & & & Hel Spit (L10) \\
\hline & & & Vistula Sandbar (L11) \\
\hline & & & Curonian Sandbar (L12) \\
\hline & & & Bernati (L13) \\
\hline & & & Kolka peninsnula (L14) \\
\hline & & & Jurmala (L15) \\
\hline & & & Rannametsa (L16) \\
\hline & & & Sestroreck (L17) \\
\hline & & & Kalajoki (L18) \\
\hline \multirow[t]{3}{*}{$\mathrm{M}$} & \multirow[t]{3}{*}{$\begin{array}{l}\text { Machair type } \\
\text { coast (M) }\end{array}$} & \multirow{3}{*}{$\begin{array}{l}\text { Very flat and surface sands similar to machair dunes } \\
\text { (M) - low accumulation, in calm bays, predominated by } \\
\text { sea not aeolian sediment, with shells, without signifi- } \\
\text { cant forms, mainly covered by reed thicket. }\end{array}$} & $\begin{array}{l}\text { Gulf of Gdańsk and Puck-Meche- } \\
\text { linki meadows (M1) }\end{array}$ \\
\hline & & & North Estonia (M2) \\
\hline & & & $\begin{array}{l}\text { Northern Finland and Sweden } \\
\text { (M3) }\end{array}$ \\
\hline \multirow[t]{8}{*}{$\mathrm{N}$} & \multirow{8}{*}{$\begin{array}{l}\text { Foredunes - } \\
\text { chain of ridges } \\
(\mathrm{N})\end{array}$} & \multirow{8}{*}{$\begin{array}{l}\text { Typical, coastal dune- foredune }(\mathrm{N}) \text { - in form of longi- } \\
\text { tudinal ridge or separated hillocks or dome forms that } \\
\text { are factor of coastal progradation. The chain of forms } \\
\text { presenting coast development. }\end{array}$} & Darss promontory (N1) \\
\hline & & & Usedom Island, North (N2) \\
\hline & & & Swina Gate Sandbar (N3) \\
\hline & & & Hel spit promontory (N4) \\
\hline & & & Vistula river mouth (N5) \\
\hline & & & Kolka promontory (N6) \\
\hline & & & Hiiumaa Island (N7) \\
\hline & & & Narva Sandbar (N8) \\
\hline
\end{tabular}


Sea) epitomises the permanent presence of coastal dunes around the Baltic Sea and the relative differences between them: the dune formations aggregated in an area of $22 \mathrm{~km}^{2}$ represent an outstanding morphological diversity, from prograding foreland and promontories, both with small foredunes and sand bodies blown away landwards to organic accumulation (with wetlands/ marshes) which always accompany the back side of sand barriers to dunes, distributed along the $25 \mathrm{~km}$ of the coastline, that may be encountered elsewhere around the Baltic Sea. Thus, the island can serve as a model of the Baltic Sea sandy coast.

\section{Sweden: narrow sandy coasts with low dunes in the region of Scania}

Sandy beaches are common along the coasts of southern Sweden, in the region of Scania, divided by a moraine shore, in contrast to the northern Swedish coast which is mostly rocky. In Scania, the sandy coast extends along about $25 \%$ of the coastline (Bontje et al. 2016). In southern Sweden, dunes are very low due to the beach being narrow and the quantity of the sediment being insufficient (Fig. 2A-C). There are four separate barrier: a $15 \mathrm{~km}$ long barrier near the town of Ystad town, in the foreland of Sandhamaren, and the longest Yngsjö dunes, $35 \mathrm{~km}$ long barrier facing the East located in Hanö Bay and double spit Falsterbo peninsula located in entrance to the Oresund.

The coast near Ystad, with a southern exposure, is generally straight, with an indentation formed by a bay lined by a sandy coast. The sediment transport in the bay follows a circulation pattern (Hanson 2002). The coast is occasionally affected by storm surge erosion (Hanson 2002,
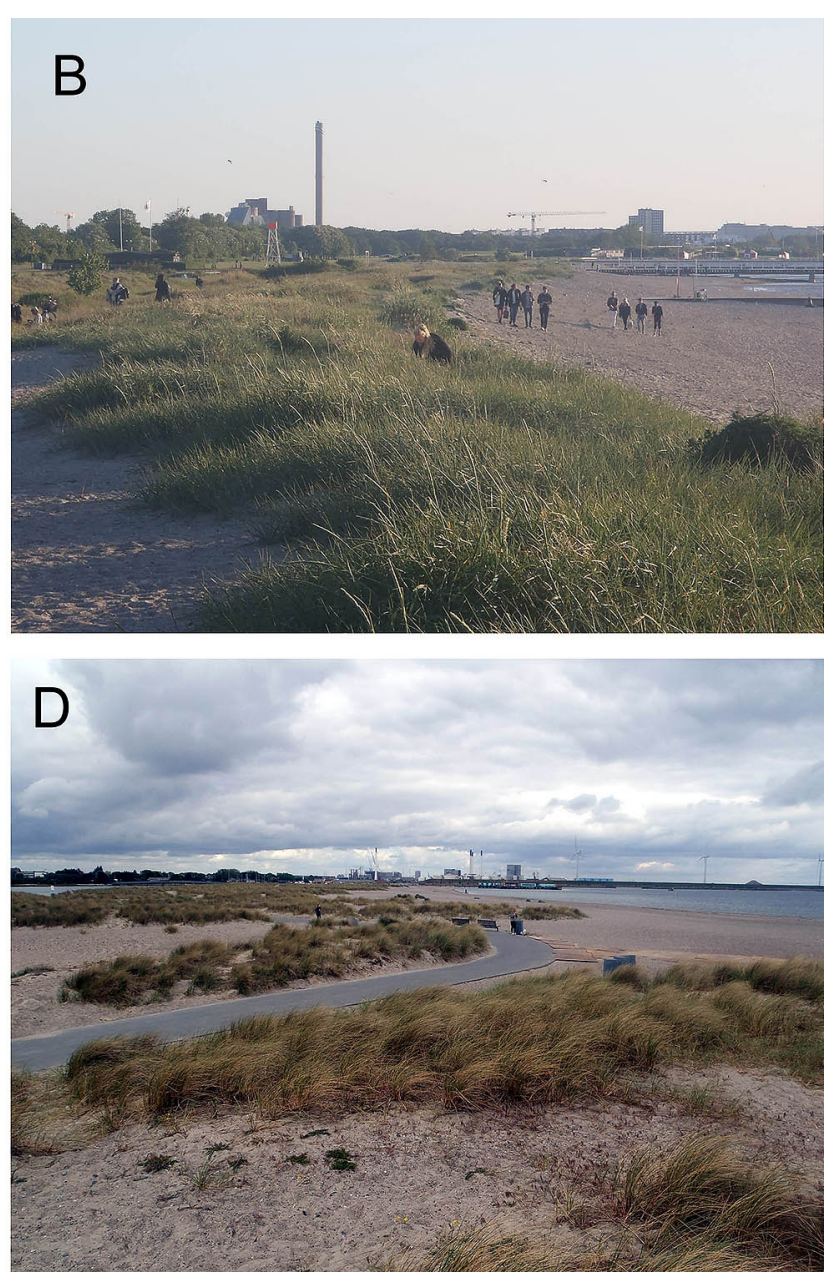
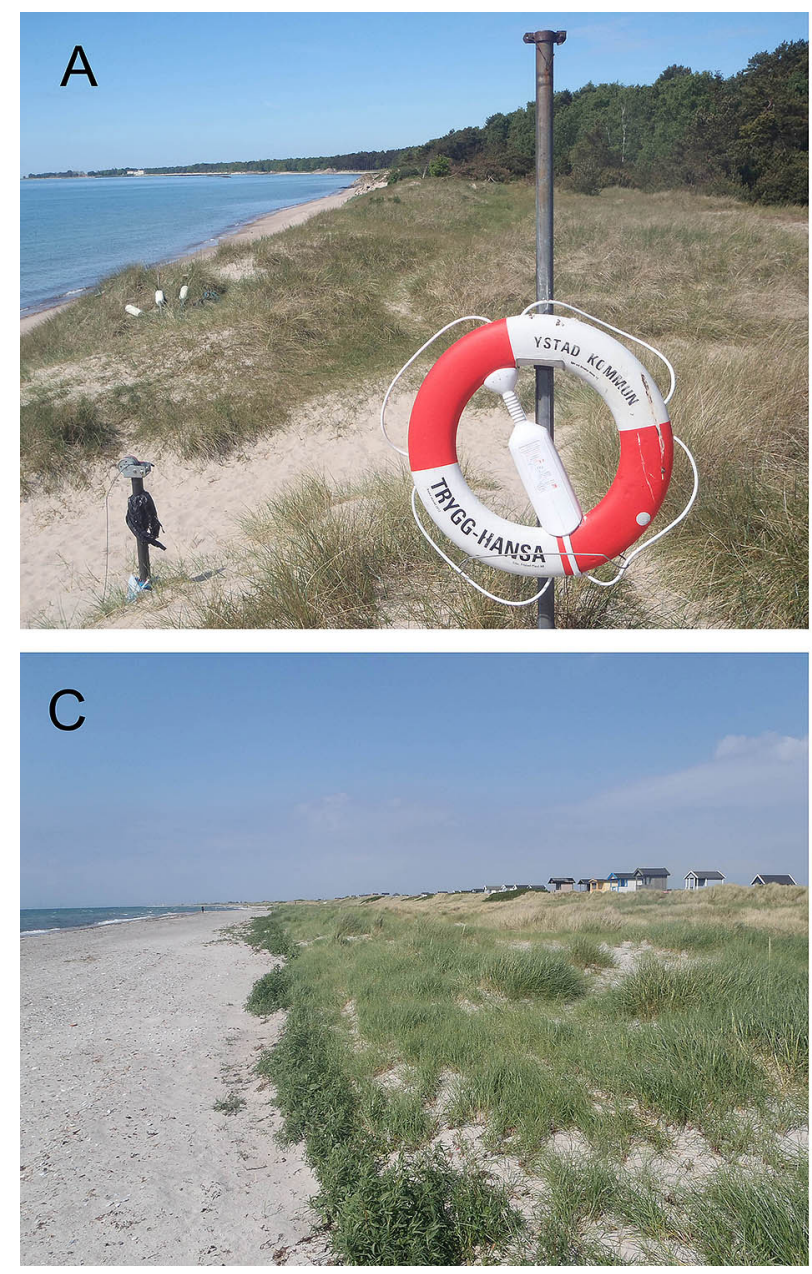

Fig. 2. Low dune ridges in North-west part of Baltic Sea (Photo T. Łabuz).

A - foredune $4 \mathrm{~m}$ high in Ystad Bay, Sweden, B - artificial dunes on Malmoe coast, Sweden, C - west coast of Falsterbo, Sweden - with young $2 \mathrm{~m}$ high and older $5 \mathrm{~m}$ high stabilized foredunes, D - artificially created dune coast on Amager beach, South part of Copenhagen, Denmark. 
Larson, Hanson 2013, Halldén 2017). In the western part of the bay, the coastline is changes by the presence of the town and harbour of Ystad. The central part of the bay's coast features two low (up to $4 \mathrm{~m}$ high) dune ridges. The eastern part of the bay is a natural reserve (Ystad Sandskog). It has a dynamic sand dune system that has long been influenced by the availability of sand that comes from longshore stream. Two sand barriers on the east coast of Scania: in Sandhamaren and Yngsjö show a similar dune relief, but are less damaged by storms due to their eastern exposure.

The western part of the Scania coast features Falsterbo, an interesting triangular spit with two developing scythes (Blomgren, Hanson 2000). Both scythes are very dynamics forms: North one is mainly eroded but still grows on its tip and South one is in prograding phase (there natural reserve is protecting embryo dunes). Dunes on the spits are $4-5 \mathrm{~m}$ high, at the back there are wetlands and small inland dunes (southern part of spit). The Falsterbo Peninsula is a sandy formation which started to form some 6,000 years ago through sedimentation around remnants of three separated and elevated moraine-clay-till hills (Blomgren, Hansen 2000). The southern, sandy coast of Sweden experiences coastal erosion. Waves that affect the coast arrive from the south-west and are particularly heavy during autumn-winter (Hansen 2002, Bontje et al. 2016). Coastal small sandy formations can be found also on the Island of Gotland (in its northern part) and Denmark's Island of Bornholm.

\section{Denmark: rare and scattered stretches of sandy coast and low dunes}

The Danish coastal land is largely a moraine landscape formed by glacial and postglacial processes. The Baltic coast of Denmark shows scattered dunes (Christiansen et al. 1990). It is the coast of the northern Jutland peninsula in the Kattegat (Skagen Spit) only that features large (up to $30 \mathrm{~m}$ high) shifting dunes (transgressive dunes called klit) and coastal foredunes that developed due the uplift of this part of Denmark. The land there is still rising, the developing dunes also shifting landwards. The Skagen Spit can be classified as a cuspate sandy foreland extending towards the north-east. The central part of the Spit shows parabolic and barchanoid dunes, shifting landwards, called the Skagen Odde (Hauerbach 1992, Anthosen et al. 1996, Clemmensen et al. 2015). Those formations were shaped, in four phases, between 1460 and $1935 \mathrm{AD}$ (Clemmensen at al. 2015).

The southern part of Denmark features areas spotted with small, more or less stable coastal dunes adjacent to salt marshes, also called salt meadows, where the coastal land is sinking at a rate of 1 to $2 \mathrm{~mm} \mathrm{a}^{-1}$. Although there are more spits covered by gravel than by sand, some narrow sandy spits and tombolos made of sandy deposits can be encountered. Those formations support very narrow and low (up to $3 \mathrm{~m}$ high) foredunes covered by psammophilous grass, some of which are described below. The Stokken is a barrier island which fences off the low-lying marshy coast of the Laeso Island from south. The 5-km long, Albuen Spit is located on the Lolland Island, its concave scythe-shaped tip marking the termination of its development. The Hyllkerog, a 17-km long, narrow and straight scythe, is a similar spit in the south-eastern part of Lolland. The Sjaelland Odde is a semi-sandy spit formed as a tombolo by longshore currents shaping the moraine land and islands. In some places, e.g. the Amager beach in the southern part of Copenhagen, narrow barriers, aided by nourishment, have been rebuilt with beaches and artificial dunes (Andersen, Jensen 1994). The Koga Bay located south of Copenhagen features a $25-\mathrm{km}$ long, young gravel and sandy barrier that has developed during the last 200 years. In 1978-1983, its development was aided by human activities (Hansen, Vestergaard 1986). The area, like other parts of the Danish coast, is highly developed and serves tourist purposes. Another interesting sandy formation, the already mentioned Island of Anholt $\left(22 \mathrm{~km}^{2}\right.$ surface area) is located in the middle of the Kattegat (Clemmensen et al. 2007, 2011).

\section{Germany: diverse shores with scattered dune coasts}

The German Baltic Sea coastline stretches from the Danish border in the west over $2481 \mathrm{~km}$ to the Polish border in the east $(536 \mathrm{~km}$ in the Federal State of Schleswig-Holstein and $1945 \mathrm{~km}$ in the Federal State of Mecklenburg-Vorpommern). Most low-lying coasts with dunes are located in the eastern part within the Federal State of 
Mecklenburg-Vorpommern, with only a few dunes further to the west (Lampe 1996, 2002). Today's coastal morphology and types largely reflect the glacial features that became partly submerged during the Littorina transgression: glacial basins, tunnel valleys, and large sandy deposits (Lampe 2002, Hoffmann et al. 2005). In the western part of the coast, the lack of sediments (due mainly to land subsidence and less so to erosion) largely prevented the development of large sandy spits and dunes, with a few exceptions like the Bottsand near Kiel (2.5 km long), Heiligenhafen (5 km long) or Graswarder $(5 \mathrm{~km}$ long) South of Fehmarn. In the eastern part, the rising sea formed an archipelago with many small moraine cores, including large blocks of undisturbed sediments from the Cretaceous (chalk cliffs of the Island of Rügen) projecting out of the water to form several islands. Since the wave energy increases from the west towards the east (due to the prevalence of westerly winds), sand accumulation and dune development are more common towards the east: the accumulated sediments form sandy spits, barrier islands, and similar features eventually connecting moraine cores, which leads to the so-called mature coastline.

The most important beach and dune systems along the German Baltic Sea coast can be found along the Fischland-Darss-Zingst peninsula (Fig $3 \mathrm{~A}, \mathrm{~B})$, on the islands of Hiddensee and Rügen (Fig. 3C, D) as well as on the Usedom Island (Fig. 4A-C), (Lampe 2002, Schumacher 2002a, b, Hoffman 2004). The Darss peninsula (almost 25 $\mathrm{km}$ long) is covered by a number of low sandy foredunes that have developed during the last 5,000 years and are separated by swampy areas. The peninsula's promontory is in its progressive phase, with erosion in the western and north-eastern part (Fig. 3A). The western coast of the Hiddensee is being eroded by westerly storm
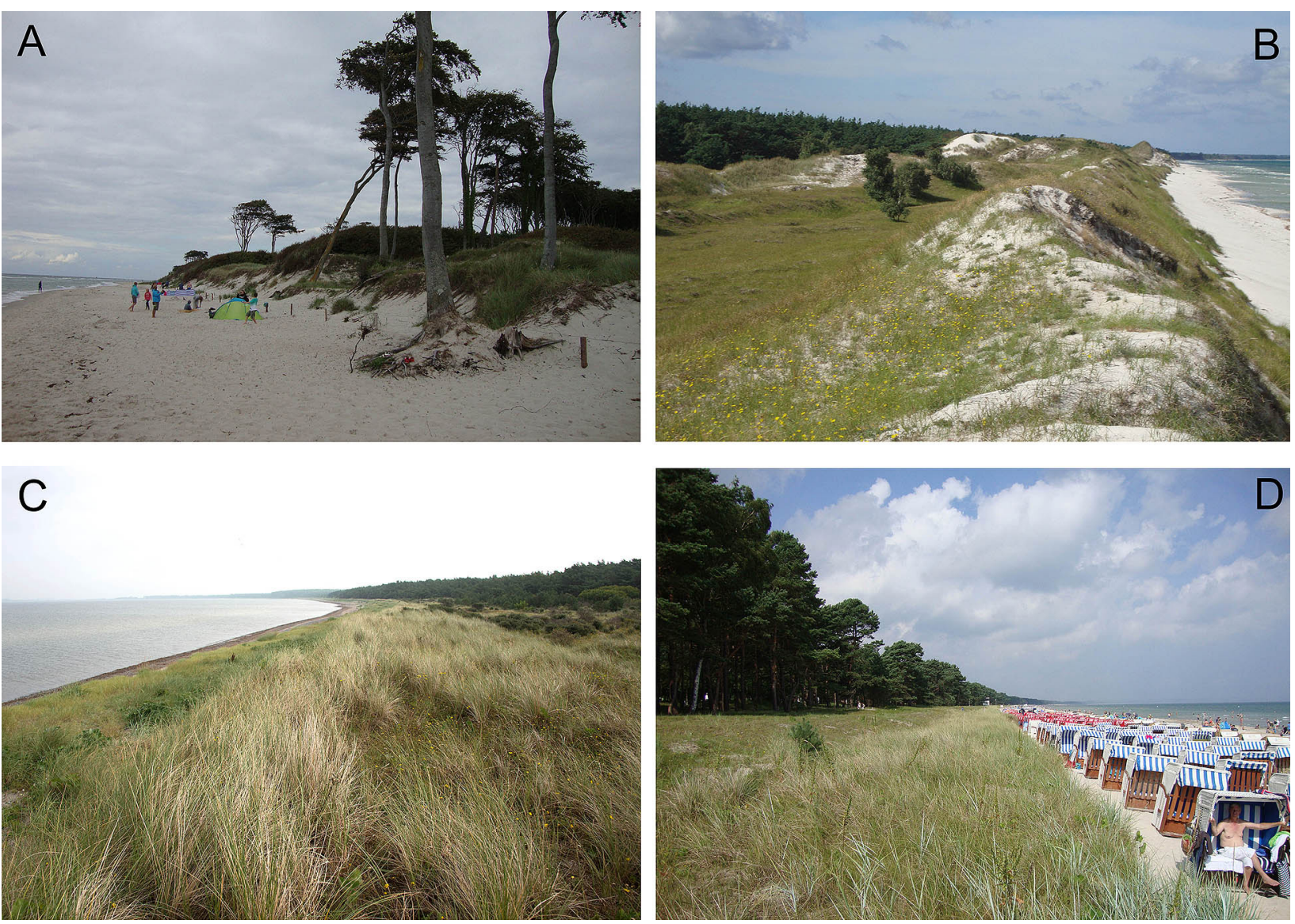

Fig. 3. Low dunes on bay and booden coast of Germany (Photo T. Łabuz).

A - eroded sides of foredunes on West coast of Darss promontory, B - eroded "Hohe dune" in Pramort, east part of Darss-Zingst peninsula, C - undisturbed beach and dune system from the Bug peninsula on Rügen Island, core zone of the National Park "Vorpommersche Bodden landschaft" (Photo R. Grunewald), D - eroded artificial dune in Binz, Schmale Heide Sandbar, Rügen Island. 

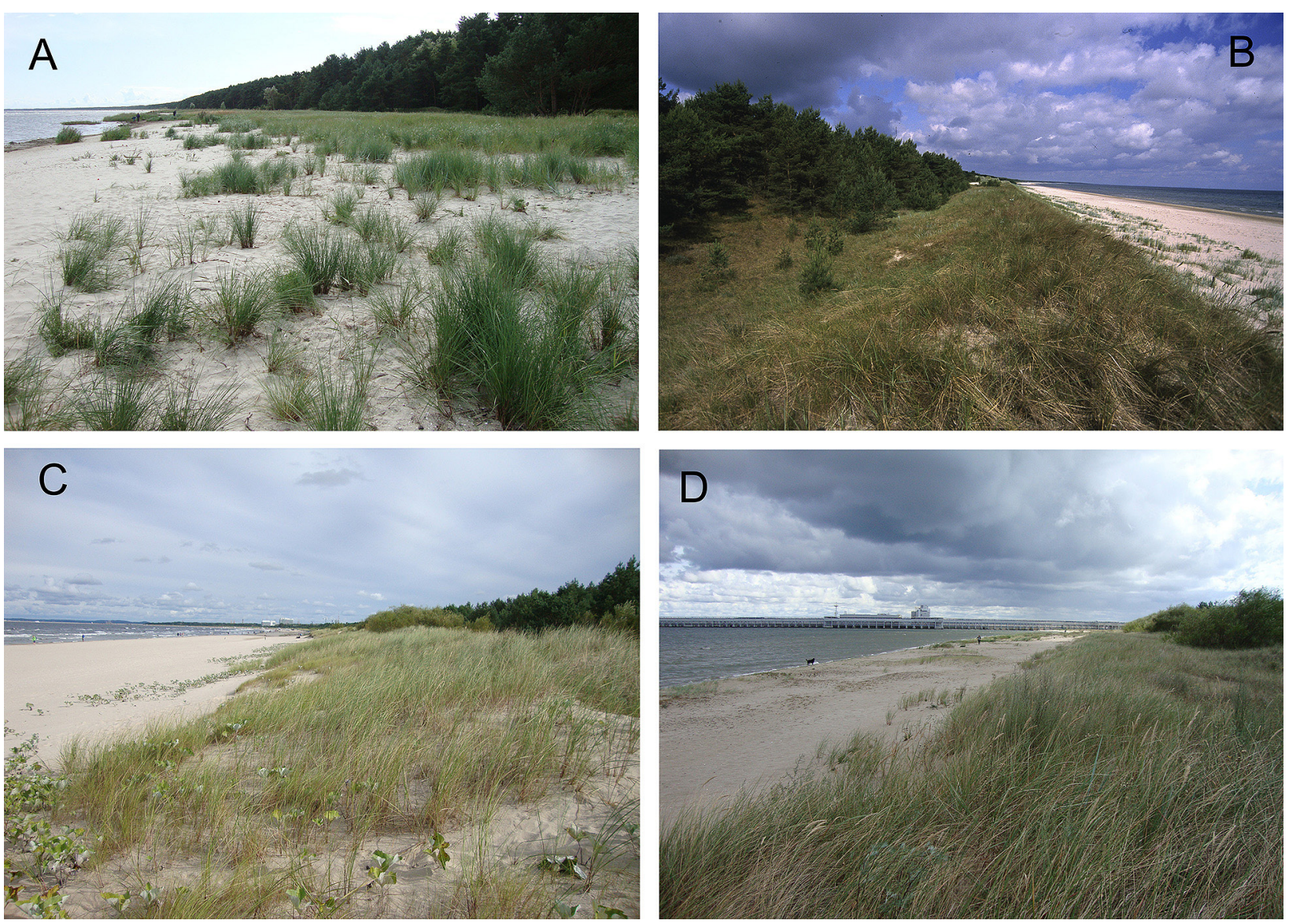

Fig. 4. Usedom and Wolin islands dune coast (Photo T. Łabuz).

A - North part of Usedom, Germany, low energy, dunes with pioneer, hallophilous grasses and reed shrub, B - little disturbed beach and dune system from Usedom Island near Karlshagen (Photo R. Grunewald), C - dune ridges on northern part of Świna Gate Sandbar, Ahlbeck, D - dune coast inside LNG harbor in Świnoujście, Poland.

surges. A very special geological feature is the Schmale Heide (Eng. The Narrow Heathland) on the Island of Rügen (10-km long). The Island of Rügen itself show cases, to a large degree, a "mature coastline". It is made up of several moraine cores which became connected by Holocene sediments, mostly sand. The Schmale Heide connects a total of three different moraine cores. However, the origin of sediments that build up this barrier and isolate the Kleiner Jasmunder Bodden from the open Baltic Sea is special, as the barrier's material contains, in addition to sand, a Pleistocene core composed of boulder clay and flint stone from deposits within the chalk deposits on the Jasmund peninsula. Several different flint stone beach ridges can be identified, reflecting different stages of the barrier. The areas closer to the present coast show dunal development and sandy beaches. The northern part of the Usedom features low dunes which create a system of formations filling the bays and connecting moraine remnants (Hoffman 2004). Similar is the southern part of the Island of Usedom where the sandy coast contains two spits extending into the Pomeranian Bay to become a part of the Świna Gate Sandbar (Keilhack 1912).

The beach and dune systems along the German Baltic Sea coast are undergoing constant change. Part of the coast is protected by different coastal structures (Lampe 1996, Gurwell 2008), including large artificial dunes and flood dykes behind them. Moreover, human-induced effects such as the climate change, tourism or coastal defense measures interfere with the natural dynamics so that only very few coastal beaches and dunes along the German Baltic Sea coast remain in an undisturbed or little disturbed state. These areas can be mostly found in strict and remote nature reserves with limited access. One example of a little-disturbed beach and dune system is provided by the Bug peninsula on the Island of Rügen (Fig. 3C); it shows drift-line communities 
as well as various dune ridges at different stages of succession and no signs of trampling or other negative impacts from recreational activities. On the other hand, Grunewald (2006a), Grunewald and Schubert (2007) showed examples of quantitative and qualitative changes in plant diversity that can be linked to human-induced disturbance. Another problem is the ruderal vegetation which can be observed mostly in the vicinity of holiday resorts or harbour areas (Isermann, Krisch 1995, Grunewald 2006b, Grunewald, Schubert 2007).

\section{Poland: a coast abounding in dunes, with high-dune formations}

The Polish coast is formed mainly by sandy sediments (Rosa 1963, Borówka 1990, Tomczak 1995a, Zawadzka-Kahlau 1999, 2012). There are two main coast types: a flat coast with a sandy belt covered by dunes, about $400 \mathrm{~km}$ long, and a glacial-origin cliff coast, which about $100 \mathrm{~km}$ long (Eabuz 2005). The shape of the Polish coastline and its exposure to predominant winds results in the coastal current pattern inducing longshore sediment transport from the central part of the coast (the Koszalin Bay) both to the west and to the east, in the so-called longshore streams (Rosa 1963, Tomczak 1995a, Racinowski, Seul 1996, Pruszak, Zawadzka 2008, Zawadzka-Kahlau 2012). Due to local dynamics and coast undulation, some sandbars show indications of accumulation, while others are affected by erosion, the accumulation sections being alternated by the eroded ones (Zawadzka-Kahlau 1999, Rotnicki, Borówka 1995, Łabuz 2013). This effect is visible mainly on the long sandy stretches between Rowy and Karwia in the mid-eastern part of the coast. More than $70 \%$ of the foredune ridges are older formations entirely covered by vegetation and recently eroded by the sea. Only $15 \%$ of the foredune coast (about $90 \mathrm{~km}$ ) is in the accumulative phase, with 1-2 foredunes being covered by pioneer vegetation. In a few locations only (the main delta of the Vistula, two sections of the Kashubian Sandbar, three section of the GardnoŁebsko lakes sandbar, and the middle section of the Swina Gate Sandbar), the coast consistently builds an active wide dune ridge that slowly grows towards the sea (Łabuz 2013).

The Polish coast shows two types of barriers (Łabuz 2013): narrow and wide. The narrow barriers, less than $0.5 \mathrm{~km}$ wide, with a single foredune or dune-free, are fronted by narrow (20 $\mathrm{m}$ wide) beaches. Such barriers can be found in the western and central parts of the Polish coast and are exemplified by the Dziwnowska, Jamno, Bukowo and Kopań lake sandbars. The wide barriers (1-2 $\mathrm{km}$ in width) are well-developed in the eastern part of the coast and feature $40-80-\mathrm{m}$ wide beaches; the examples include the Wicko, Gardno, Łebsko, Sarbsko lake sandbars and the Kashubian Sandbar. The western part of the coast is formed mainly by low cliffs and narrow barriers developed between them (Racinowski, Seul 1996, Łabuz 2009), the barriers bearing names of the nearby towns: the Międzywodzie-Dziwnów, Pogorzelica-Mrzeżyno, and Rogowo-Dźwirzyno sandbars. Their length does not exceed $15 \mathrm{~km}$. Those are short sandy sections - welded barriers that are developed in mouths of postglacial valleys filled with present rivers and small coastal lakes (mainly former lagoons). The highest sandy formations, vegetated by woodlands, are the 30-m high barchans located between Pogorzelica and Mrzeżyno. Other transverse formations up to $15-20 \mathrm{~m}$ high are located on the organic bottom between moraine hills or swampy coastal areas. There are also remnants of dune formations covering moraine and organic deposits near the town of Kołobrzeg. The central part of the Polish coast, exposed to the strongest storm surges, is mainly erosive. There are very narrow barriers with eroded foredunes, e.g. the Jamno, Bukowo, Kopań lake sandbars (Zawadzka-Kahlau 1999, 2012, Łabuz 2013, 2015b). Some of the lakes are former embayments, cut off from the sea by growing sandy spits. Others are ground moraine lakes that were flooded by the sea during the Littorina transgression. These barriers are developed on shallow clay deposits, e.g. the Wicko or Gardno lake sandbars. The barriers in the central part of the Polish coast feature the highest inland dunes developed in coastal environments (Łabuz 2013). They are mostly barchanoid and parabolic (Miszalski 1973, Borówka 2001) formations, 20-40 m high, that are at present covered by woodlands. Although forestation started in late $19^{\text {th }}$ century, most of the hills were at the shifting phase until the mid- $20^{\text {th }}$ century. At present, it is only at some sites (on a smaller scale: the wider scythe of the Hel Spit, the vicinity of Białogóra on the Kashubian welded barrier, the vicinity 

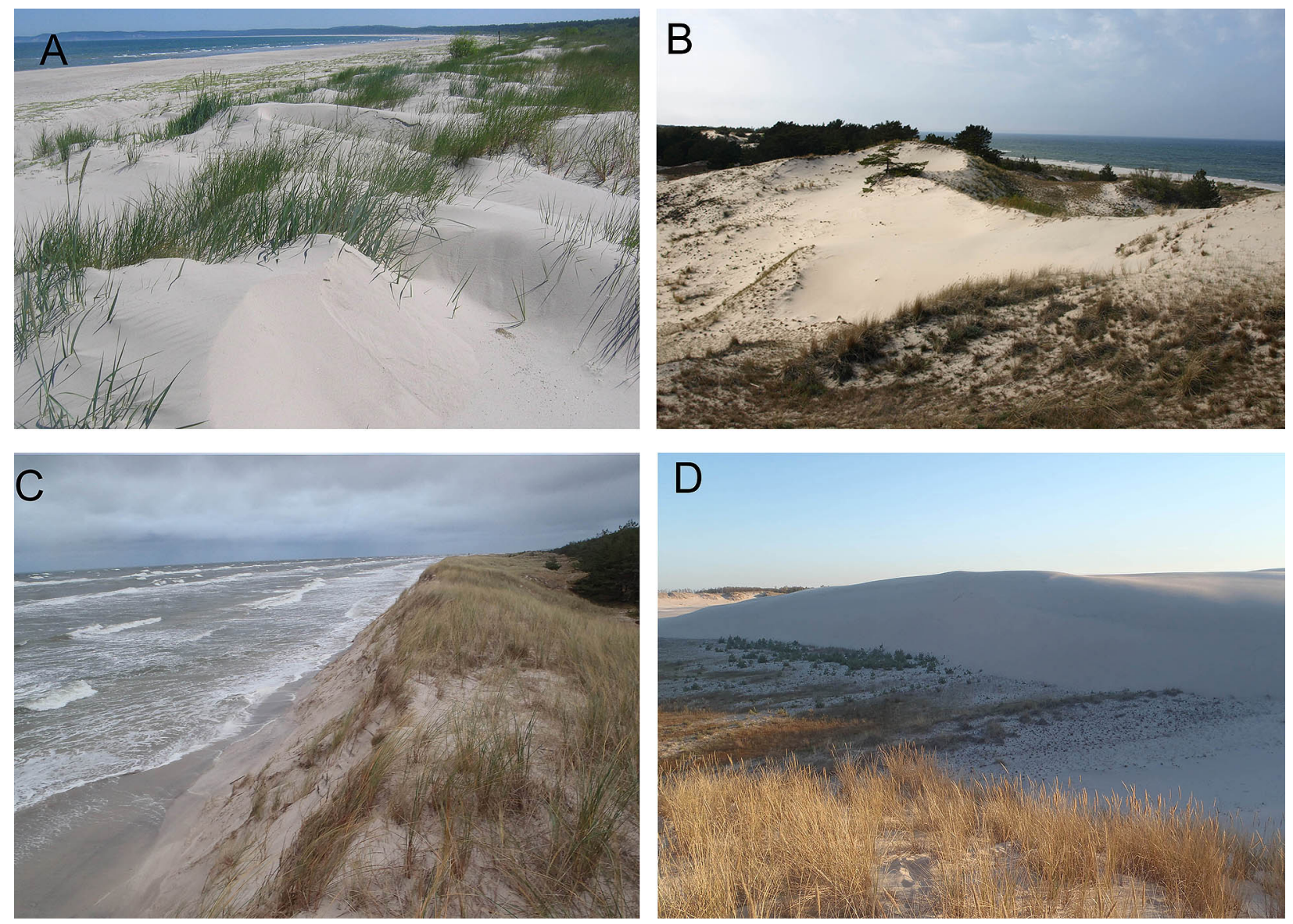

Fig. 5. Examples of well developed sandy-dune coast in Poland, South Baltic Sea (Photo T. Łabuz). A - embryo and foredune on prograding coast of Świna Gate Sandbar, B - blown off transverse dunes of Hel Spit promontory, south from Jurata, C - erosion of huge foredunes developed through last 30 years, Stilo, Kashubian

Sandbar, D - wandering dunes of Łebsko Lake Sandbar - barchan type dune is entering low-lying area.

of Dźwirzyno on the western part of the coast, and on a larger scale: the Łebsko Lake Sandbar) (Fig. 5D, 10 L, M) that inland formations are still shaped by the wind. The remaining high dunes are covered by pine forest. The Czołpinska Dune (56 $\mathrm{m}$ in height) is the highest dune still affected by aeolian deflation, while the Łącka Dune (c.a. $42 \mathrm{~m}$ in height - changing due to sand movement) is the highest shifting dune, its movement rate being estimated (from the base) at 1-2 $\mathrm{m}$ a year (Miszalski 1973, Borówka 2001).

The Świna Gate Sandbar located in the western part of the Polish coast (and extending beyond the state border into Germany) has other, and more complex origins. The length of whole barrier is $25 \mathrm{~km}$. It has been built by two spits developing from opposite directions (Keilhack 1912, Piotrowski 1999, Łabuz 2005). The Świna Gate Sandbar origins date back to the Littorina transgression (6-4 thousand years BP) which drove the mass transport into a large bay from the opposite cliffs, thus giving rise to the formation of two spits which grew in length, merged, and closed Szczecin Lagoon off from the sea. The western spit has its base in the Usedom Island (beginning from the village of Heringsdorf) and bears growing coastal and inland shifting dune formations on the western and eastern side of the town of Świnoujście, near the mouth of the Świna channel connecting the Szczecin Lagoon with the Baltic Sea (Fig. 4C, D). The eastern spit is based on the Island of Wolin cliffs and begins in the town of Międzyzdroje. The dune system grows from its roots to the Świna channel. This section of the coast shows, in its central part, one of the largest aeolian accumulations (Fig. 5A, 10N, O). A new, 5-7 $\mathrm{m}$ high foredune develops every 10-15 years (Łabuz, Grunewald 2007, Łabuz 2013). The old wandering dunes are pushed onto the old coastal (brown) ridges. They date back to the $17^{\text {th }}$ century, when deforested sand began to from a transverse ridge from small parallel coastal foredunes. 

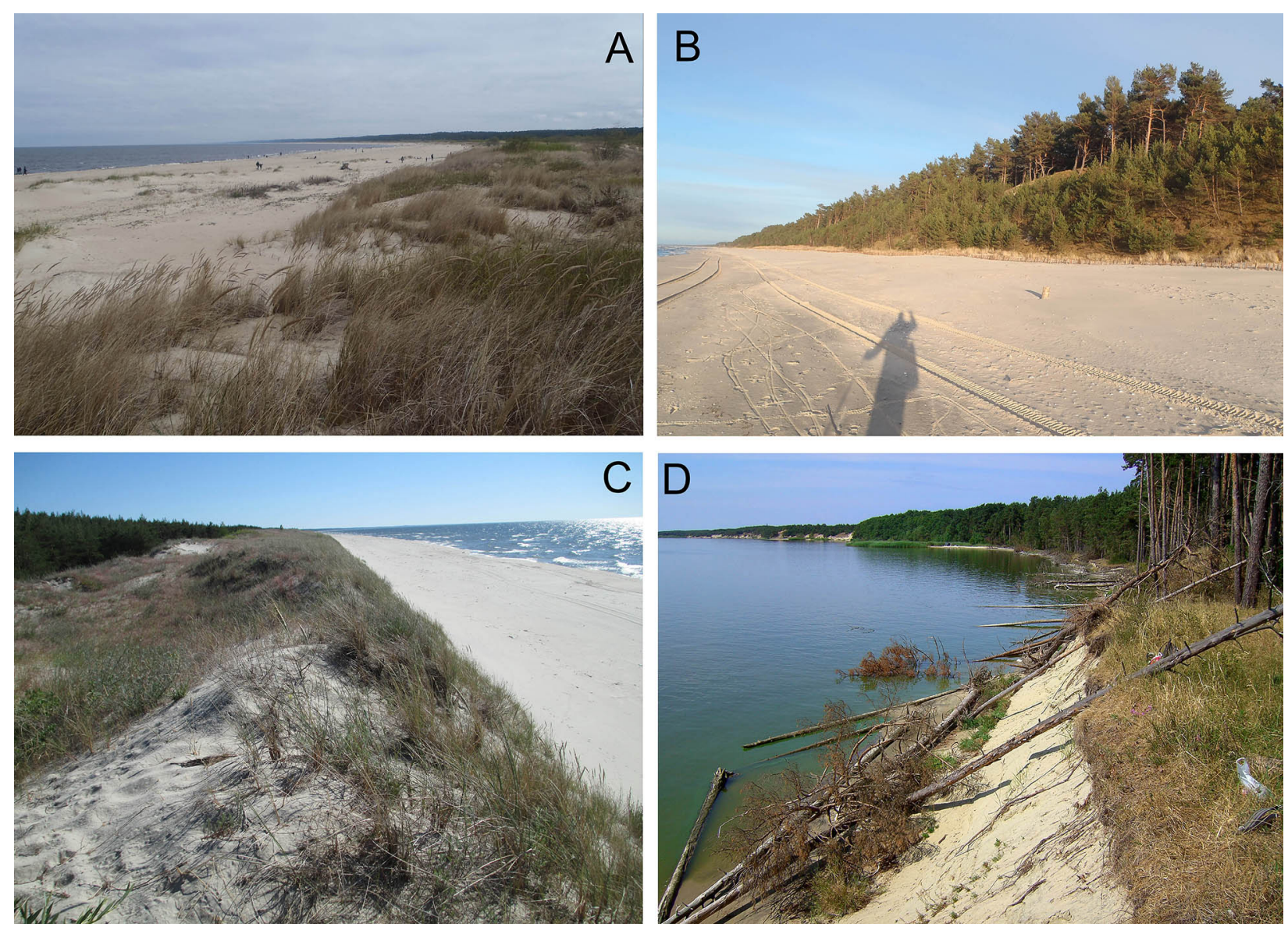

Fig. 6. Vistula Spit dunes.

A - large accumulative filed, fast progradation in Vistula delta channel (Photo T. Łabuz), B - coast build by old dunes - prove of slow coast erosion, Przebrno, middle part of spit (Photo T. Łabuz), C - foredune with erosion slope, Russian part of spit (Photo V. Bobykina). D - cut off ancient dunes entering Vistula Lagoon, Russian part of spit (Photo V. Bobykina).

Nowadays, the middle part of barrier is covered by chains of foredunes that are $5-8 \mathrm{~m}$ in height. There are up to 9 foredunes in the most accumulative part, that have been developed since 1914 (last 100 years).

The spit type barrier is represented by the Vistula Spit, an almost $110-\mathrm{km}$ long sandy strip originating near the cliff coast in the Gulf of Gdańsk and extending to the Sambian Peninsula cliffs in the Kaliningrad Oblast (Mojski 1995, Kobelyanskaya et al. 2011). The spit has developed as a concave formation filling low-lying areas and numerous outlets of the Vistula River. Three outlets of the Vistula have been, for 1,000 years, bringing sand to the coastal zone. The western part of the spit is influenced by the old mouth of the so-called Martwa Wisła (the Dead Vistula), (main mouth in years 1200-1800), Brave Vistula (main since 1840), and the Vistula channel (main since 1896). The eastern part of the spit is a product of longshore sand transport both from the west and from the east, which eventually resulted in the present-day Vistula Lagoon being fenced off from the open sea. Most sand has accumulated in the delta fan of the Vistula channel up to $4 \mathrm{~km}$ west of large breakwaters (Fig. 6A). The sand drift from the east was stopped by the construction of the Strait of Baltijsk breakwaters (Badyukova et al. 2011b, Kobelyanskaya et al. 2009, 2011). The eastern part of the spit, within Poland, is the oldest, the part in Russia's Kaliningrad Oblast is the youngest. It is still not clear when the whole spit become a sandy barrier (spit). The younger part belonging to Russia, for long time has been made of separate islands (Badyukova et al. 2011b). The entire west-south part of spit is covered by old, brown foredunes, dating back to $6,000-5,000$ years ago (Fedorowicz et al. 2009), and by transgressive dunes: a longitudinal, transverse forms in the western part. 
In younger middle part spit is covered by concave transverse forms and in youngest, eastern (in Russia) by parabolic, dissected ridges and large plains. The relief of transverse inland forms along whole spit differ because coast exposition is changing for prevailing westerly winds (Fig. 6B-D, $10 \mathrm{H}-\mathrm{I})$. The highest peak is close to the Polish-Russian border - Camel Hump, $47 \mathrm{~m}$ a.s.l.

The smaller Hel Spit is famous for its shape; it is a single sand body, developed from western coastal cliffs in the direction of the Gulf of Gdańsk (Tomczak 1995b). At present, the spit is $36 \mathrm{~km}$ long. It is very narrow in its western part, affected by erosion and artificially nourished, and widens up at its 3,000-year-old tip (Tomczak 1995b). The tip of the spit is covered by numerous older and low foredune ridges (Fig. 5B). The Spit's shape and morphology are typical of the scythe formation's development, with new land growth being accompanied by a new coastal ridge (Eabuz 2013). The promontory of Hel Spit is covered by number of foredunes and larger previously wandering forms (Fig. 10J). The Puck Bay (a lagoon) situated south of the spit shows a very complex submerged relief (Rucińska-Zjadacz et al. 2009) which may suggest phases of the Spit development different from those known from the literature. The spit's growth about 6,000 years ago could have progressed further north, and the spit's shape and exposure could have been different from the present state due to cliff retreat during the Littorina transgression.

The largest and longest dune belt is located in the eastern-central part of the coast (Eabuz 2013), between Rowy and Karwia, the section including the Łebsko-Gardno lakes, Sarbsko lake and Kashubian lowland barriers. The almost $75-\mathrm{km}$ long stretch of the coast is covered by foredunes, older coastal ridges, formerly shifting stabilized dunes or wandering coastal formations built by elevated sand structures as well as low depressions and long sections of foredunes, which together separate the lakes and marshes of the coastal lowland from the coast (Fig. 5C).

\section{Russia's Kaliningrad Zone: extensive dune shores of long spits}

The Baltic Sea coastline within the Kaliningrad Oblast' is about $150 \mathrm{~km}$ long, including $48 \mathrm{~km}$ of the Curonian Spit and $25 \mathrm{~km}$ of the Vistula Spit.
These spits separate the Vistula and the Curonian lagoons, respectively, from the Baltic Sea. Their respective widths are $0.3-1.8 \mathrm{~km}$ and $0.35-4 \mathrm{~km}$, the highest altitudes being 25 and $67 \mathrm{~m}$. Those large bay-bar spits in the south-eastern part of the Baltic Sea coast, extending over $50 \%$ of the Kaliningrad Oblast' shoreline, show coastal dunes located both on the seaward and lagoon sides of the spits on account of the history of spit formation during the Holocene transgression.

Along the curves of the smoothened-up sea shore of the Baltic Sea, both spits exhibit foredunes, the youngest formations, covered by psammophilous grasses and bushes and separated from the sea by sandy beaches. Their condition (erosion, stability or growth) depends, to a great extent, on the accumulation of loose material on the underwater coastal slope, on the exposure of certain parts of the shore to the wind regime, as well as on the anthropogenic factors (Badyukova et al. 2008, 2011a, b). All the dunes, irrespective of their modern form and magnitude (Fig. 6C), have, in their evolution, undergone a sequence of foredune formation stages (Badyukova et al. 2008, Kobelyanskaya et al. 2011, Mojski 1995). Ancient dunes on the lagoon side are forested, with the exception of three open dune masses on the Curonian Spit shore. The actively washed foredunes on the Russian part of the Vistula Spit make up about $50 \%$ of the coast line, while of the Curonian Spit - 47\% (Boldyriev, Bobykina 2005).

The foredune on the Vistula Spit coast is 4 $\mathrm{m}$ high at its northern end and 8-10 $\mathrm{m}$ high in its central part near the Polish-Russian border (Bobykina 2007, 2014, Badyukova et al. 2011b, Kobelyanskaya et al. 2009, 2011, Bobykina et al. 2016). Within the first $200 \mathrm{~m}$, south of the Baltyjsk Strait, at the Kosa settlement, the foredune is completely degraded. The central part of the Spit, where accumulation is stable, supports a combination of all modern aeolian formations (Fig. 6C): a foredune, 2 incipient dunes leaned to its base, and a wide shadow dune covered by grass. The foredune is dissected by wind hollows, up to 30 hollows being observed in 2004. At the back of these hollows, 12-15 m high aeolian hills have formed (Bobykina et al. 2016).

From the Vistula Lagoon side, there are separate dune masses - ridges of high ancient (mostly parabolic) dunes with a steep eroded slope facing the lagoon (Boldyriev, Bobykina 2001, 2008, 
Badyukova et al. 2011b). The eroded dune base is lined by a narrow ( 0 to $10-12 \mathrm{~m}$ ) beach. The flooded slopes of ancient dunes retreat at an average rate of $0.4-0.8 \mathrm{~m}$ a year. In some years, the edges of the ancient dunes or terraces were observed to have retreated by $4 \mathrm{~m}$ (Fig. 6D).
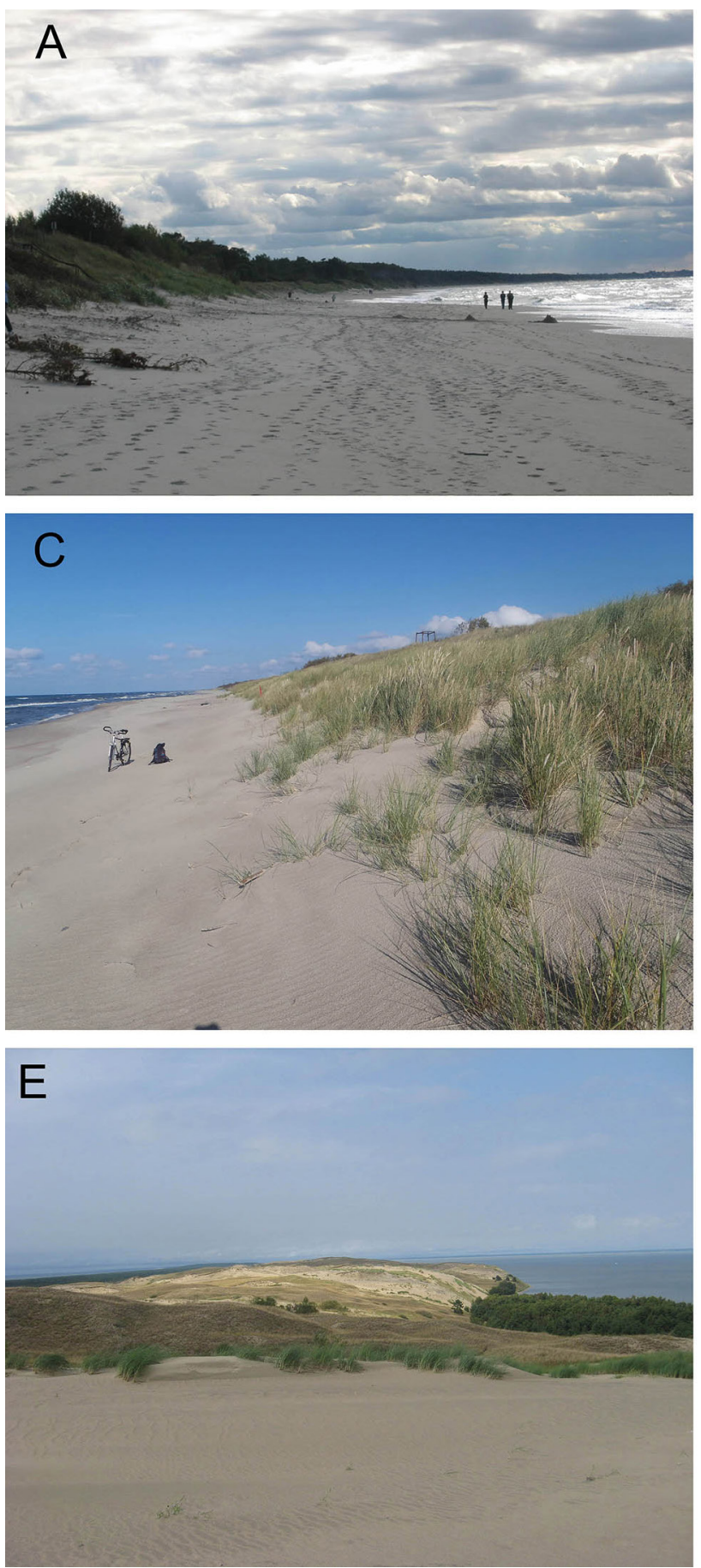

In its root part, the sandy coast of the Curonian Spit contains fragments of foredunes. The foredune in the central part of the spit, to the border with Lithuania, is to 9-10 $\mathrm{m}$ high and $80-100 \mathrm{~m}$ wide (Fig. 7A). The whole formation is dissected by a large number of wind hollows; 170 were
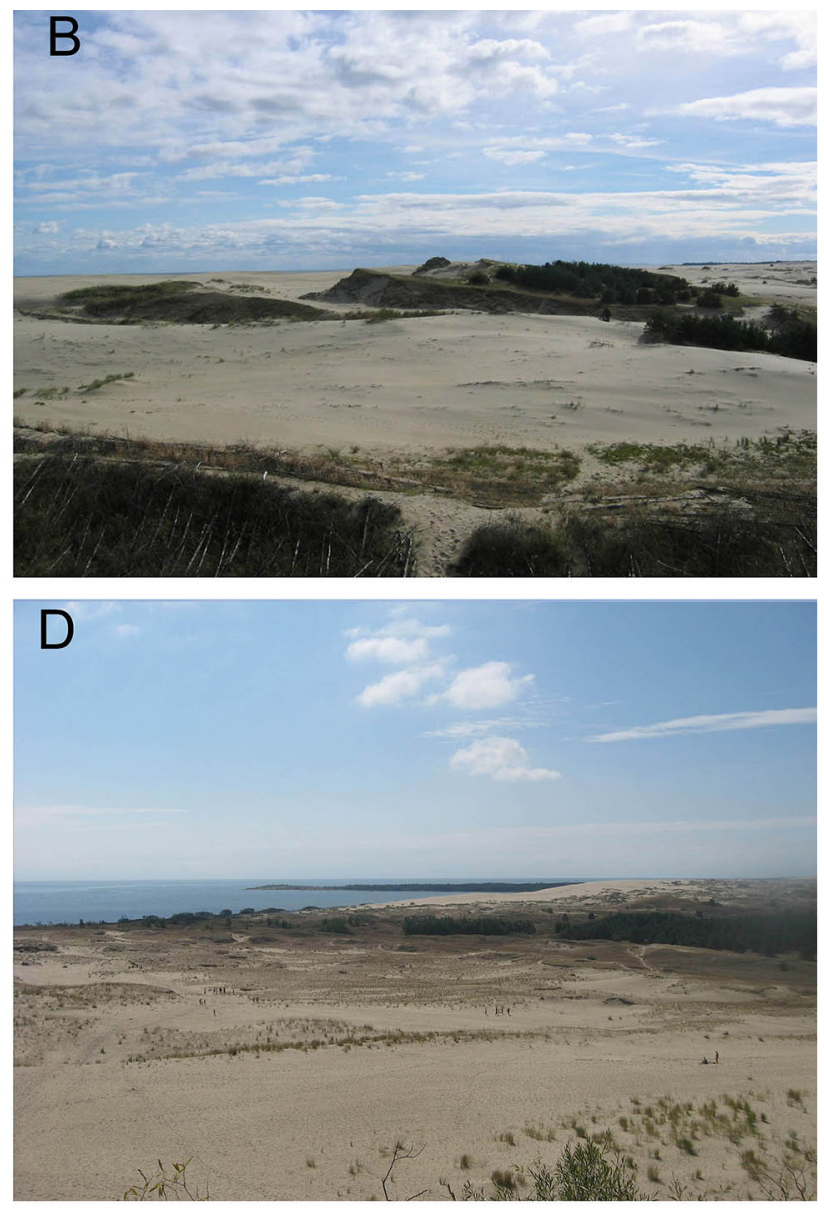

$\mathrm{F}$

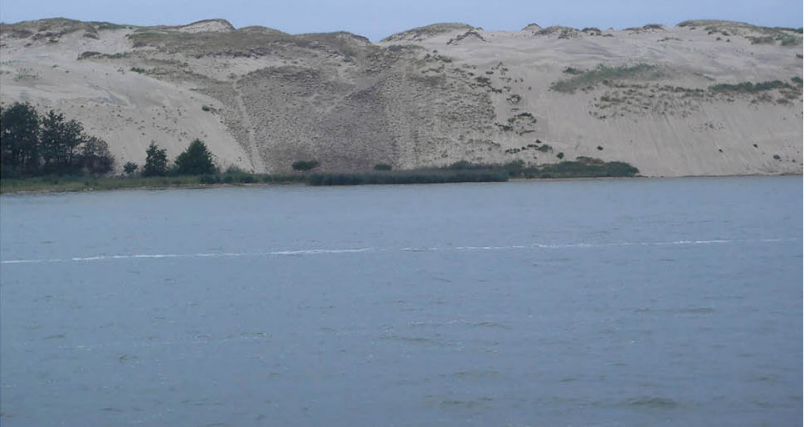

Fig. 7. Curonian Spit dunes (Photo T. Łabuz).

A - coastal dunes in Lesnoj, Russia, B - deflation and wandering dunes on Efa Dune (62 m high), near Morskoje, Russia, C - coast build by foredune just near Lithuanian and Russian border, D - open sands on Main Ridge, Lithuania and Russia border near Nida (Photo A. Česnulevičius), E - wandering dunes, partly covered by vegetation in middle part of spit, Lithuania (Photo A. Česnulevičius), F - active sand entering Curonian Lagoon, North from Pervalka. 
recorded in 2005 (Boldyriev, Bobykina 2008) and 333 in 2016 (Burnashov, Karmanov 2016). The hollows may be related to the coast being exposed to frequent and heavy westerly winds. The entire Curonian Spit sea coast experiences deficiency of sand supply. The Curonian Spit coast features ridges of high ancient dunes, from 40 to $62-65 \mathrm{~m}$ high and 700 to $1200 \mathrm{~m}$ wide (Fig. 7B). Nearly all the dune ridges and masses are artificially forested, except for 4 areas between the kilometres 17 and 75 of the spit where chains of moving dunes have been left in their natural state. Masses of moving high dunes face the Curonian Lagoon with a steep leeward slope (Fig. 10G). The highest shifting form located South of Morskoje village is called Efa Dune (62-64 m a.s.l.). In some places, the slopes are separated from the lagoon by low terraces $2.5-3.5 \mathrm{~m}$ high. The wind erosion contributes to their degradation and propagation of the coast into the lagoon (Zhamoida et al. 2009, Badyukova et al. 2011a). The forested ancient dunes, approaching the lagoon coast, are being actively eroded, a situation being similar to that on the Vistula Spit.

\section{Lithuania: shifting dunes on the largest sandy spit}

The Lithuanian zone of the Baltic Sea is situated in the south-eastern part of the Baltic Proper (Gudelis 1998).The shoreline, from the Russian (Kaliningrad) border on the Curonian Spit (Kursiu nerija) to the Latvian border on the mainland, is $94 \mathrm{~km}$ long (Žilinskas, Jarmalavičius 1997, Bitinas et al. 2005, Žilinskas 2005, Žaromskis, Gulbinskas 2010, Jarmalavičius et al. 2006). The state and development of the shoreline depends greatly on the sea level fluctuations, wave dynamics, and neo-tectonic movements (Kabailienè 1996, Gudelis 1998), the factors indirectly affecting the foredune situation. The sand bank on the seashore decides on subsequent aeolian processes, which have formed the inland dune ridge (Gudelis, Michaliukaitè 1976).

The Lithuanian Baltic Sea coast is divided into two parts: the mainland and spit. The mainland coast features only narrow and low foredune ridges the maximum relative altitude and width of which is as little as 5-7 $\mathrm{m}$ and up to $30-60 \mathrm{~m}$, respectively (Fig. 8A). In the northern part of the Lithuania Baltic Sea coast (the Butingè section), the foredune ridge has completely disappeared due to marine erosion processes. In the vicinity of coastal towns of Klaipeda and Palanga, beach and dune restoration plays an important role. The towns are separated by a coastal stretch showing a single, low and narrow dune, backed by a low-lying coastal plain covered by peat and lacustrine deposits. This coast is type of welded barrier adjacent to the land.

The foredune ridges on the Curonian Spit are higher and wider (Fig. 7C). Their maximum relative height and widths are 12-15 $\mathrm{m}$ and 50-100 $\mathrm{m}$, respectively. At the front of the ridges, there appear shadow dunes, locally as separate hillocks covered by grass throughout the year. The foredune, which is either in the accumulative or erosional phase, is backed by a flat plain called Palve. It is mostly of deflation origin, and is devoid of accumulative sand formations. This deflation form is locally covered by $5-8 \mathrm{~m}$ high accumulation moulds (Česnulevičius et al. 2017) and is in places wider than 80-300 m. Large sand dunes are found behind this zone, their most recent origin is known from 200 years of observations on a range of formations, from open sandy to partly forested (in the $19^{\text {th }}$ century) ones. The largest dune formations developed due to medieval deforestation (Česnulevičius et al. 1998, Povilanskas 2009).

The so-called Main Dune Ridge has a complicated relief (Česnulevičius et al. 1998, 2006, 2017): at early stages, it was formed as parabolic dunes, to become more complex later on. The rate of the development of the present formations can be explained by deflation and shifting of blown dunes. The Main Dune Ridge is $40-64 \mathrm{~m}$ in relative (Fig. 7D-F); the highest dune form along Baltic Sea coast is Vecekrugo Dune - $67 \mathrm{~m}$ high transverse form, forested again in $19^{\text {th }}$ century ridge (Fig. $10 \mathrm{E})$.

The Main Dune Ridge shows two blowing dune segments: one in Juodkrantè - Pervalka and the other South of Nida (Fig. 10F). Two highest shifting forms are: Vinko Dune - $51 \mathrm{~m}$ high and Pandziro Dune - 52 to $56 \mathrm{~m}$ high. Detailed studies of these segments showed the surface to be made complex by micro- and meso-aeolian forms investigated so far: hollows, scarps, passages, corridors and terraces (Česnulevičius, Morkūnaitè 1998, Česnulevičius et al. 2006, 2017, Morkūnaitè, Česnulevičius 2005, Morkūnaitè et al. 2017). The 

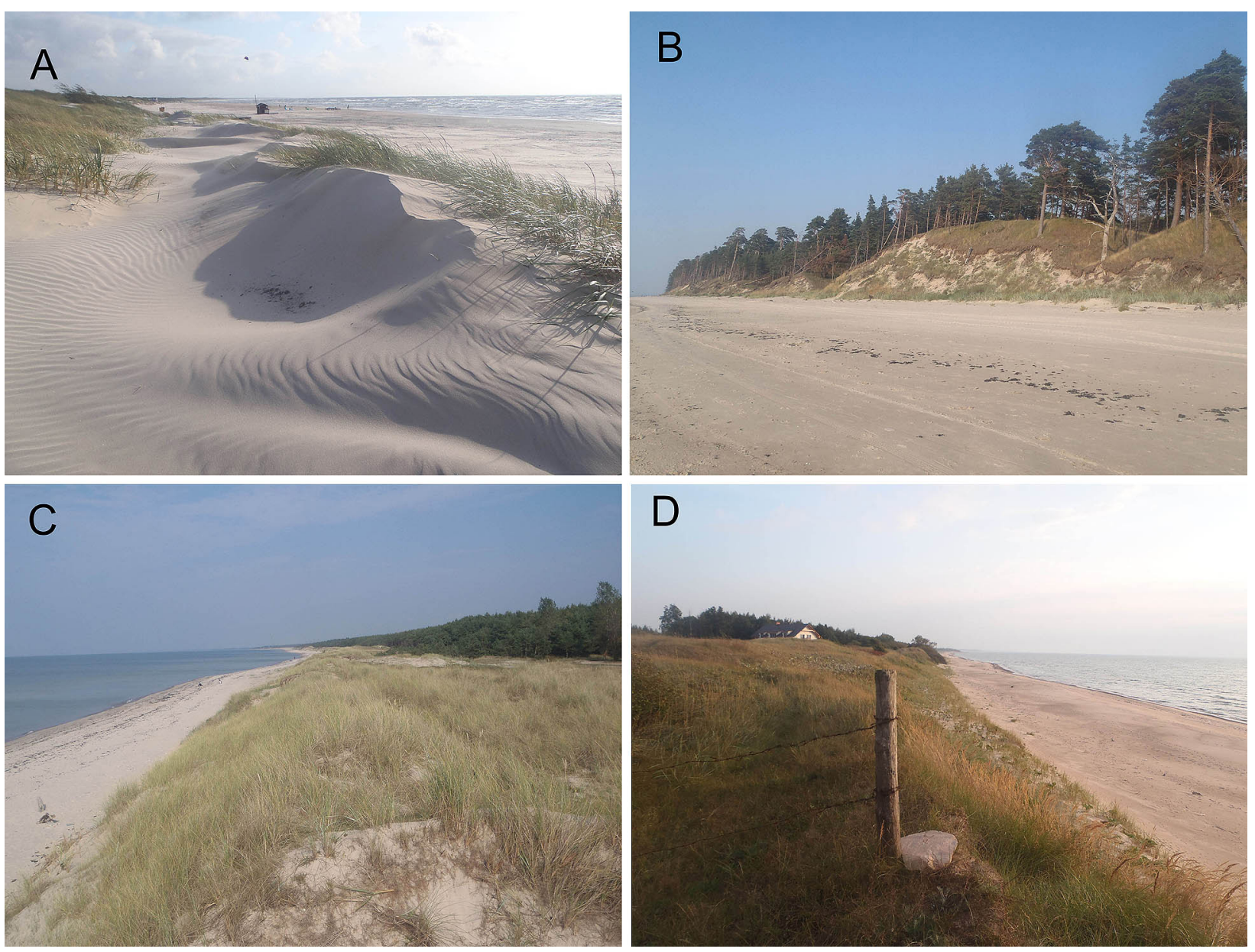

Fig. 8. Dunes of East Baltic coast (Photo T. Łabuz).

A - active foredunes in Sventoji, North Lithuania, B - eroded former wandering dunes near Bernati, Latvia, C - foredune North from Liepaja, Latvia, D - dunes on low moraine cliff, Ziemupe, middle Latvian coast.

largest relief changes are measured on East proximal slopes of these huge sand forms. The areas investigated between 1999-2015 reveal intensive deflation and accumulation due to aeolian processes that shape still shifting sand bodies. Composite depressions and wastelands, open to the lagoon, are mostly distributed from Cape Lydumas toward the Vinkis Dune (Morkūnaitè et al. 2017).

\section{Latvia: long sandy coasts with diverse dune formations}

The sea coast of Latvia extends over some 490 $\mathrm{km}$, including $182 \mathrm{~km}$ along the Baltic Sea Proper and $308 \mathrm{~km}$ in the Gulf of Riga (Eberhards 1998, 2003). That part of the Baltic Sea coast is exposed to the westerly winds and storm surges. The relief of foredunes between the open coast of the Baltic Sea and the Gulf of Riga shores varies due to coastal dynamics, studied by several authors (Eberhards, Saltupe 1995, Povilanskas 2002, Koltsova, Belakova 2009, Soomere et al. 2011). The coast with foredune (white dune) complexes takes up $230 \mathrm{~km}(45 \%)$ of the shoreline, the dunes being interspersed by stretches of coastal meadows or narrow beaches bordered by forests or cliffs. Sandy beaches occurring along $240 \mathrm{~km}$ of the coast are the dominant shore form. The remaining part is made up of low moraine cliffs covered by gravel and boulders.

The Gulf of Riga near Jurmala, where the rivers Daugava and Lielupe open up to the sea, is a highly popular tourist area (Povilanskas 2002). The coast is built by two arc-shaped barriers, exposed northwards. The coastal dunes are lower than those on the open Baltic coast and rise up to 4-5 $\mathrm{m}$. The gulf coast is affected by storm surges caused mostly by the northerly to north-westerly winds (Eberhards et al. 2009). The area features 
also older dune forms which, until the $18^{\text {th }}$ century, had been shifting. The southern part of the gulf coast, bisected by the Lielupe River, is a former barrier covered by 15-18 m high transverse dunes. Further North, between the rivers Gauja and Inčupe in Saulkrasti, on the Vidzeme coast of the gulf, there are several inland sandy bodies that are separated by lagoons and swampy areas. One of the most famous higher dunes is the Balta Kapa, an $18 \mathrm{~m}$ high former inland hill.

Cape Kolka is a sandy foreland covered by a number of former foredunes. In its central part, there are 7-13 m high inland dunes (Eberhards 1998) that form a transgressive dune field, nowadays covered by woodland. In the northern part of Kolka's cuspate spit, there is a large shoal which slowly nourishes the coast with sand. The sand drift along the open Baltic coast of the spit proceeds from the south northwards. The western part of the coastal zone is built by low dune ridges affected by alternating periods of erosion and accumulation. There are several small rivers, that supply sand for the beach-dune development. The coastal dunes are up to $6 \mathrm{~m}$ high. Due to strong winds and storm surges from West direction, the western coast is threatened by erosion. Although the eastern coast is shielded by the tip (promontory) of Cape Kolka, the foredune is narrow and eroded by sea waves. The back of the beach is built by a number of low (up to $2 \mathrm{~m}$ high) coastal ridges. There are also stretches of a higher sandy coast: the Evažu Hill near the town of Melnsils (Fig. 10C), and further South a higher Pūrciems Hill (20 m high) located $0.8 \mathrm{~km}$ away from the coast, that emerged 6,000 years ago. Cape Kolka features the Slitere National Park known for its diverse wetland and dune landscapes (many higher chains of dunes are located inland).

The whole southern coast of Latvia is built by low (up to $4-5 \mathrm{~m}$ high) dune ridges separating swamps or lagoons from the sea (Fig. 8C, D). A long barrier-like section is found South of Liepaja, in the vicinity of a large lagoon. The main coastal dune system, $60 \mathrm{~km}$ long, extends from Liepaja towards the Lithuanian border. It contains eroded and accumulated sections where the Liepaja waterbreakers stop the sand transport from the South, which leads to enlargement of the coastal dune belt in the southern part of the town. The shore around the harbour has been highly transformed by old fortifications. The coast between Liepaja and Bernāti is built by higher transverse inland dunes, with foredune absent due to permanent erosion (Fig. 8B). Towards the South, the narrow sandy strip widens up to 1-2 $\mathrm{km}$ near the village of Bernāti. Further South, between Cape Bernāti and Cape Mietrags, the beach and the dune coast have been undergoing increased erosion over the recent decades (Eberhards 2003). However, there are several dune ridges, covered by pine forest, indicative of former coastal progradation. This belt is backed by a marshy wetland. The coast further south of Bernāti features 6-7 m high foredunes oscillating between erosion and accumulation. Towards the Lithuanian coast, the beaches become narrow and covered by gravel material. There is a unique protected area representing the coastal dune and wetland ecosystem.

In the central part of this stretch of the coast, a large (almost $30 \mathrm{~km}$ long) dune belt, formed during the Littorina stage, has developed. The dunes there are arc-shaped formations connected into a single long ridge. This transgressive dune field is located $0.2-0.8 \mathrm{~m}$ from the coast. The dunes, blown away from the coast, encroached on land and covered former foredunes (some of which can still be found at the back of the ridge). The dune formations shaped by the westerly winds are, on the average, more than $25 \mathrm{~m}$ high. The highest peak is the Pūsēnu Hill (37 m), located South of Bernāti; it is a forested elevation with the shoreward slope still bare, with sparse grass vegetation. This dune, the highest along the open eastern Latvian Baltic coast, had been mobile until 1835 when it was stabilised by foresting after several houses were buried in sand (Fig. 10D).

\section{Estonia: scarce sandy coasts, narrow bay barriers}

Estonia is experiencing land uplift, its maximum present rate reaching nearly $3 \mathrm{~mm} \mathrm{a}^{-1}$ (Kall et al. 2016). For this reason, the coastal dunes are variable in time and scale (Orviku et al. 2003, Ratas et al. 2008, 2011). Estonian dune landscapes are situated at some distance from the shore and at different elevations above the sea level (Ratas, Rivis 2003). Only some foredunes and embryo dunes can be found in the active shore zone (Fig. 9A-C). The greatest coastal dune formation is located on the west-facing coast, where 

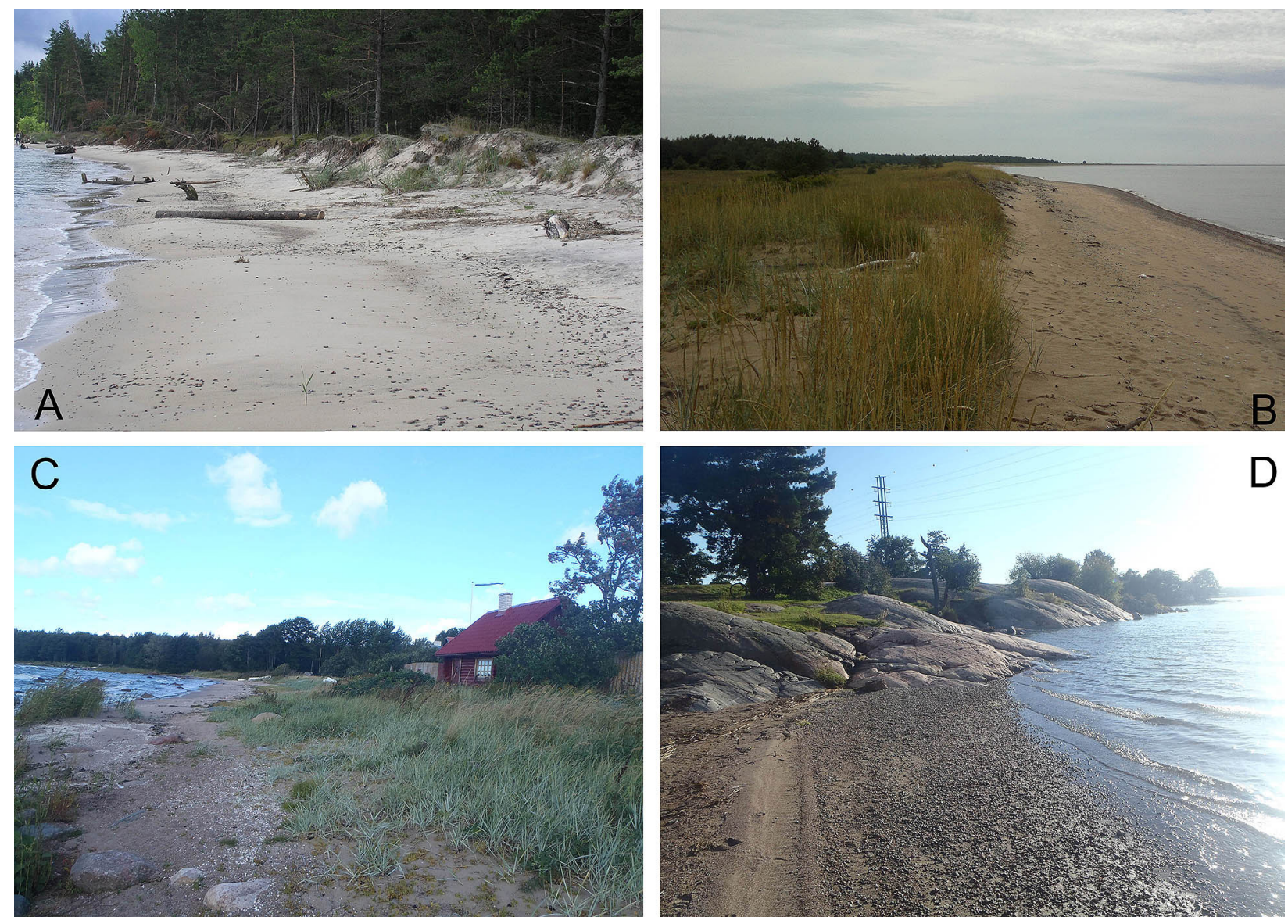

Fig. 9. Low and scarce sandy coast in North-east part of Baltic Sea.

A - foredune ridges plain, Harilaid, Estonia (Photo H. Tõnisson), B - erosion of low sandy coast at Tahnkuna site, northern Hiiumaa, Estonia (Photo H. Tõnisson), C - very narrow and low sandy coast on rocky basement, Kiiu Abla, North from Tallinn, Estonia (Photo T. Łabuz), D - pocket beach with ephemeral embryo forms surrounded by rocky coast, Helsinki, Finland (Photo T. Łabuz).

the westerly winds prevail. The largest dunes, up to 20-25 $\mathrm{m}$ high, formed during the transgressive phases of the Baltic Ice Lake, Ancylus Lake, and Littorina Sea. The formation of higher dunes here is hindered by the lack of sand, humid climate and continuous land uplift.

Larger dune systems are found mainly in the north-western (Kõpu Peninsula, Keibu etc.) and south-western (Rannametsa, Tõstamaa, etc.) sections of Estonian coast (Kose et al. 2002). The Rannametsa dune system is one of the most representative dune areas. It consists of two dune ridges of different age, separated by an ancient lagoon filled up with bog deposits (the Tolkuse Bog), (Kose et al. 2002). The eastern side of the Tolkuse basin is fringed by up to $20 \mathrm{~m}$ a.s.l. coastal dunes which were partially re-blown during post-Ancylus Lake periods. The altitude of the dune foot rises in northwards from about 7 to 11 $\mathrm{m}$ a.s.l. (Habicht et al. 2017). This dune ridge is approximately $15 \mathrm{~km}$ long. The highest dunes at Rannametsa (also the highest in Estonia) reach up to $34 \mathrm{~m}$ a.s.l. - Tornimägi Hill; their relative height is being about $20 \mathrm{~m}$ (Fig. 10A). These are located on the western side of the Tolkuse Bog as a 40$\mathrm{km}$ long ridge. This high, transverse dune ridge is probably originating from Litorina Sea coastal formations from 5,500 BP (Kose et al. 2002 after Kessel, Raukas 1967).

In the eastern part of country, the contemporary seashore shows only low, mostly 1-2 m high, foredune ridges at Narva-Jõesuu, at the northern coast of the Kõpu Peninsula or in Keibu (Orviku, Romm 1992, Rosentau et al. 2013). These forms at Narva-Jõesuu, can be found also inland, so this is example of coast progaradation.

Characteristic of many Estonian coastal sites are the so-called foredune-ridge plains. These consist of a number of shore-parallel ridges, starting from today's shoreline and continuing 
several kilometres inland (Vilumaa et al. 2016). It is often difficult to find out the main factor responsible for forming these sand-built rhythmic patterns: is it the wind or hydrodynamic agents (waves, sea level variations) or a combination of both? Nevertheless, the apparent sea level fall at a location is one of the most important factors for such beach ridge development. Sand is gradually accumulating on the backshore as a result of aeolian and wave activity (Suursaar, Tõnisson 2017), while storms wash those accumulative forms periodically, forming a distinctive scarp at a specific elevation (Tõnisson et al. 2008, Tõnisson et al. 2013).

A remarkable dune belt, continuing along the whole northern coast of the Hiiumaa Island and also visible in the north-western part of Estonia was described by Vilumaa et al. (2016). It seems that the dune belt overrides the older shore-parallel foredune ridges, and the new aeolian accretion is partly covering older ridges there. In the northern part of the Hiiumaa, the base of the dune belt is mostly $4-5 \mathrm{~m}$ a.s.l., and its relative height reaches often $10 \mathrm{~m}$. The age of this dune is estimated at about 1,200 years or younger, but its exact formation mechanism is not known. Various theories include extreme events such as a massive ice attack, tsunami, or intense aeolian activity during a period of windy and cold climates (Anderson et al. 2014,Vilumaa et al. 2016). During several decades, most of Estonian coastal dunes were located in the restricted border zone of the Soviet Union and were not accessible to the population. Therefore, most of the dunes were naturally vegetated and sand was thus fixed. Today, coastal dune landscapes have a chiefly recreational value and their intensive use may have unfavourable consequences (Ratas, Rivis 2003).

\section{Russia: few sandy coast stretches in the Gulf of Finland}

Near the mouth of the Narva River, there are larger sandy coast stretches covered by foredunes, both on the Estonian and on the Russian side. There is number of similar foredune ridges presenting coast progradation due to ongoing uplift. This barrier is built by sand accumulated by the Narva, the present mouth of the river being bisected by the Russian-Estonian border (Orviku, Romm 1992, Rosentau et al. 2013).
The eastern part of the Gulf of Finland shows two major areas of sandy coast. In the vicinity of the village of Bolshaia Izhora, there are cusp-like beaches with elongated spits. These formations were described in detail by Ryachbuk et al. (2011). In the easternmost part of the Gulf of Finland, near the town of Sestroreck and the Sestra River mouth, there is a $10 \mathrm{~km}$ long and $1.5 \mathrm{~km}$ wide bay-barrier that separates a large lake from the sea. The area developed as a land after the sea level drop due to permanent uplift (Ryachbuk et al. 2009, 2011). The coast there is built by $2-3$ $\mathrm{m}$ high separate foredune hillocks or by round, flat accumulative surfaces. This is the Baltic Sea's northernmost well-developed long sandy barrier. Further North, in Finland, dunes are narrower and sand-impoverished.

\section{Finland: very sparse dunes - sandy spots on narrow uplifting promontories}

As the Earth crust is uplifting, new land emerges from the sea at the coast of Finland. The rate of land uplift varies from $8 \mathrm{~mm} \mathrm{a}^{-1}$ on the north-western coast to $4 \mathrm{~mm} \mathrm{a}^{-1}$ in the south-western part (Lehvo et al. 1998). The almost 39,000 $\mathrm{km}$ Finnish coast is rocky. The sea retreat is being accompanied by emergence of new coastal formations: the rocky, gravelly or sandy coasts, with over 200 gravel and sandy tombolos, 370 small and narrow bays, and 82 lakes identified (Schwartz et al. 1989, Tolvanen et al. 2004).

The Gulf of Finland coast features barrier, gravel and sandy shores occupying $12 \%$ of its length. Sandy shores are very rare, developed on the gravelly shores (Fig. 9D). This is why there are almost no sandy coasts with dune formations, the few such formations occurring as scattered spots at the rocky coast (Hellemaa 1998). A typical coastal dune landscape in Finland shows low and narrow sandy dunes filling quiescent bays or tombolos of the rocky, uplifted coast (e.g. the Hanko promontory). The dunes are distinctly different from those occurring in other parts of the Baltic sandy coast, and are very narrow, low, less dynamic and young. Near Helsinki, such a sandy strip can be found in a waveless bay filled by natural and artificially supplied sand. In other places, there are predominantly rocky shores with narrow beaches and 1-2 $\mathrm{m}$ high dunes. The Hanko peninsula dunes, at $39 \mathrm{~m}$ a.s.l., are 

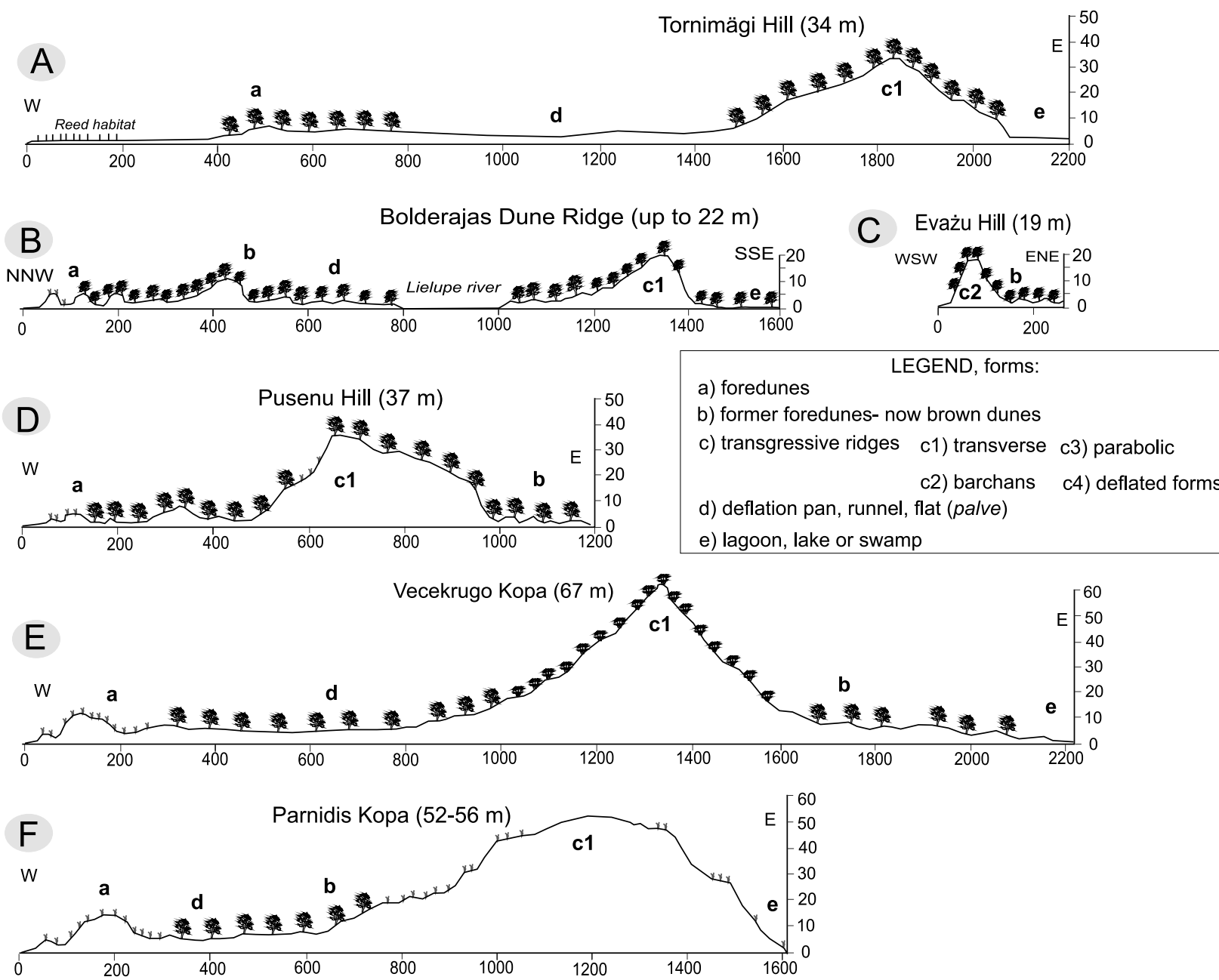

Fig. 10. The examples of highest and largest transverse dunes in each section of Baltic Sea coast (height in $\mathrm{m}$ a.s.l., distance in $\mathrm{m}$ ), location on Fig. 1 (Łabuz 2017).

A - Tornirmägi Hill, 34 m, Rannametsa dunes, Estonia, B - Bolderajas Dune Ridge, 20 m, Jurmala Sandbar, Latvia, C - Evažu Hill, 19 m, south-east Cape Kolka, Latvia, D - Pusenu Hill, 37 m, Bernati coast, Latvia, E - Vecekrugo Kopa, 67 m, North Curonian Spit, Lithuania, F - Parnidis Kopa, 52-56 m, Nida, Curonian Spit, Lithuanian/Russian border.

4,000 years old; the youngest dunes (at up to $5 \mathrm{~m}$ a.s.l.) are 900 years old, whereas the dunes near Kalajoki, also at $5 \mathrm{~m}$ a.s.l. are about 300 years old (Donner, Simola 1977).

Other areas with narrow dune coasts include the Yyteri beach near Pori, the coast near Nykalreby, Cape Vattaja (near the town of Lohtaja), and a sandy shore developed on the uplifting land near Kalajoki and a local river mouth (Hellemaa 1998). At each of these sites, dunes are narrow and located at a different ground level. The coast is nourished by discharges of the adjacent rivers and emerging sea bottom. The evidence of uplift is clearly visible in the area of the recent Uusilathi Lake, its dry, emerged bottom having been transformed into a flat dune field. In the $19^{\text {th }}$ and $20^{\text {th }}$ centuries, vegetation in this area have been grazed by sheep, which led to the development of shifting barchan-shape formations (Kosekela, Sievänen 2009). The coast near Kalajoki is very diverse, with spits, tombolos, and bays. Such diversified shoreline originated under the influence of the uplifting seafloor and its relief. There is one of the largest Finnish transgressive dune fields, with a transverse ridge up to $11 \mathrm{~m}$ high, where the absence of vegetation in the $20^{\text {th }}$ century led to burial of the adjacent forest (Heikkinen, Tikanen 1987). The coastal sandy areas in the northern part of Finland resemble meadows called the machair. Those are flat sandy surfaces covered by dense grass. The best example of a machair dune is provided by the eastern part of the cuspate Tauvo peninsula, which progrades at a rate of up to $25 \mathrm{~m}$ a year 

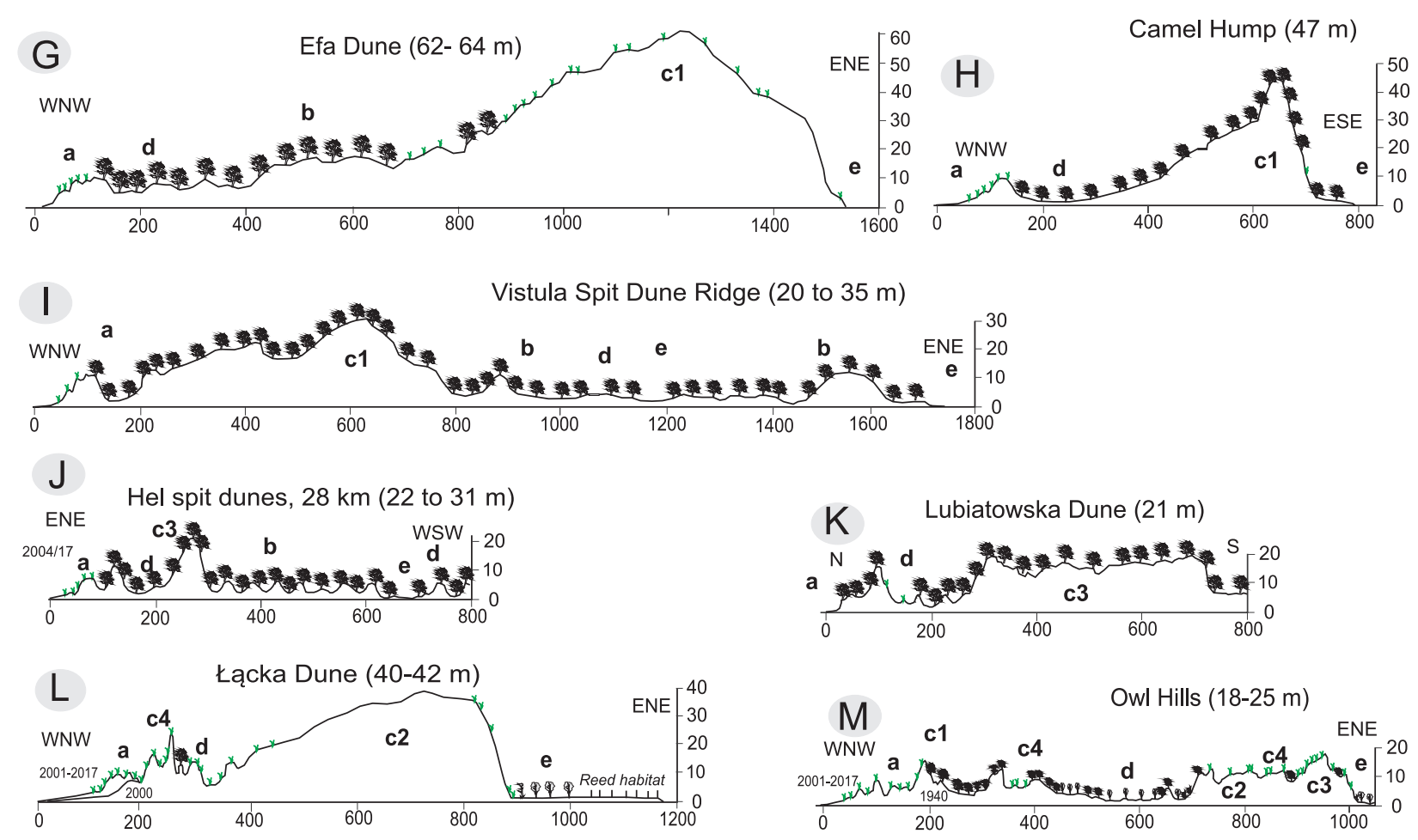

Swina barrier ridge (up to $22 \mathrm{~m}$ )

German coast dunes up to $16 \mathrm{~m}$
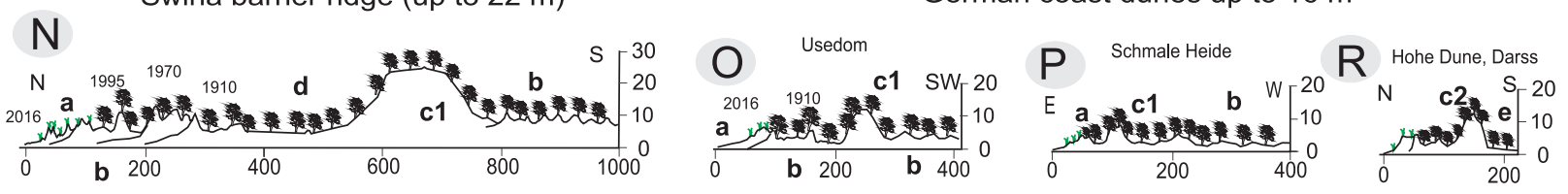

Fig. 10. The examples of highest and largest transverse dunes in each section of Baltic Sea coast (height in $\mathrm{m}$ a.s.l., distance in m), location on Fig. 1 (Łabuz 2017).

G - Efa Dune 62-64 m, Curonian Spit, Morskoje, Russia, H - Camel Hump, 47 m, Vistula Spit, close to Poland/Russian border, I - longitudinal transverse ridge on Vistula Spit, 20-35 m, Poland, J - Hel Spit promontory, semi-parabolic forms 22 to $31 \mathrm{~m}$, Poland, K - Lubiatowska Dune - parabolic, $21 \mathrm{~m}$, Kashubian Sandbar, Poland, L - Łącka Dune barchans, 40-42 m, Łebsko Lake Sandbar, Poland, M - Owl Hills - deflated parabolic, 18-25 m, Łebsko Lake Sandbar, Poland, N - transverse ridge of Świna Gate Sandbar, up to 22 m, Poland, O - transverse ridge of Świna Gate Sandbar, 14 m, near Ahlbeck, Germany, P - transverse ridge on Schmale Heide Sandbar, 12 m, Rügen Island, Germany, R Höhe Dune, remnant of transverse form, 17 m, Darss-Zingst peninsula, Germany.

(as determined based on aerial photographs in 1975-2015). The low dune, shaped like an aeolian surface, has the total length of $5 \mathrm{~km}$ (with the Vihaspauha Spit). The area is nourished by the adjacent Siikajoki River mouth.

\section{Conclusions}

The value of dunes lies in the morphologically diverse landscape shaped by storm surges and wind, with a contribution of pioneering vegetation. This environment is a habitat supporting small animals. From the human point of view, it is a natural landscape providing leisure opportunities and valuable coastal land protection against flooding. Despite their high ecological value, many coastal dune systems in the southern and the eastern parts of the Baltic Sea coast have been heavily degraded over the last centuries following the exploitation of their natural resources, settlement expansion, and industrial growth.

Vegetation plays a key role in sand stabilisation and relief stability; however, a dense plant cover may prevent dunes from developing due to dampening the wind. On the other hand, a sandy surface that is devoid of vegetation tends to be deflated. That is why the removal of coastal forests in the $17^{\text {th }}$ and $18^{\text {th }}$ centuries led to new inland dune migration. Some of such migrating dunes encroached on the lagoons (e.g. the Curonian Lagoon, Łebsko Lake), while others 
buried villages (e.g. the old Łeba and Piaski in Poland and Bernati in Latvia).

The permanent sand supply by prevailing winds is vital for the development of coastal dunes and larger inland sand bodies. The majority of these large inland formations along the Baltic Sea coast are nowadays stabilised. Only those in the central part of the Polish coast (e.g. the Łebsko Lake Sandbar) and the Curonian Spit dunes are in the state of shifting.

The largest and longest sandy coasts are found at the southern and the eastern coasts of the Baltic Sea (Table 2, Fig. 10). The shoreline there is mainly straight, dunes forming due to its exposure to frequent winds. There are large inland forms and long barriers exposed to erosion by westerly and north-westerly storm surges. The dunes have been shaped by the heavy and frequent westerly winds. Consequently, the coasts exposed to the East (e.g. the Gulf of Gdańsk and the Island of Rügen barriers) usually feature very low dunes and are mainly devoid of larger inland forms. The south-facing coasts show smaller foredunes as well (e.g. in Scania). The scarcity of sand material in the western part of the Baltic coast has resulted in a diversified coastline covered by low dunes (e.g. Denmark, Germany, even the western part of the Polish coast). Some of the barriers developed due to sandy cliff erosion, others being formed on account of river discharges. In the northern part of the Baltic Sea, dunes are narrow, and a sandy coast is rare; however, due to the land uplift, a new sandy coast emerges mainly in narrow bays featuring river mouths.

\section{Acknowledgments}

This publication is one of the results of being held cooperation and knowledge exchange between authors (R. Grunewald worked as freelance consultant outside of BfN office and views reflect his personal opinion; V. Bobykina and B. Chubarenko were supported by theme FASO No 0149-2018-0012). We would like to thank many scientists, that have studied Baltic Sea sandy coast, those whose results served to create this collective work. This publication may be first step for wider study of Baltic Sea sandy coasts in future. The authors would like to thank two anonymous reviewers for their constructive work. We are also grateful for language correction.
This scientific cooperation is in commemoration of the $100^{\text {th }}$ anniversary of the Polish Geographical Society in 2018.

\section{References}

Andersen U.A., Jensen J., 1994. Man-made landscapes at the Danish Baltic coast. In: V. Gudelis, R. Povilanskas, A. Roepstorff (eds.), Coastal Conservation and management in the Baltic region. Proceedings of the EUCC-WWF Conference 2-8.05 1994, Riga-Klajpeda-Kaliningrad, 59-68.

Anderson A., Vilumaa K., Tõnisson H., Kont A., Ratas U. Suuroja S., 2014. Geomorphology of coastal formations on present and ancient sandy coasts. Journal of Coastal Research, Special Issue 70: 90-95.

Anthosen K.L., Clemmensen L.B., Jensen J.H., 1996. Evolution of a dune from crescentic to parabolic form in response to short-term climatic changes: Råbjerg Mile, Skagen Odde, Denmark. Geomorphology 17(1-3): 63-77.

Badyukova E.N., Zhindarev L.A., Lukyanova S.A., Solovieva G.D., 2008. Development of barrier-lagoon systems in the South-Eastern Baltic Sea (in Russian). Oceanology 48(4): 641-647.

Badyukova E.N., Zhindarev L.A., Lukyanova S.A., Solovieva G.D., 2011b. Modern accretive processes along lagoon coast of the Curonian Spit, South-East of the Baltic Sea (in Russian). In: Construction of the Artificial Lands in the Coastal and Offshore Areas. Proceedings of the 2 International Conference Novosibirsk, August 1-6, 2011. Novosibirsk, SBRAS Publ.: 80-85.

Badyukova E.N., Zhindariev L.A., Lukyanova S.A., Soloveva G.D., 2011a. The geological-geomorphological structure of the Baltic Vistula Spit. Oceanology 51(4): 675-682

Bitinas A., Žaromski R., Gulbinskas S., Damusytė A., Žilinskas G., Jarmalavičius D., 2005. The results of integrated investigations of the Lithuanian coast of the Baltic Sea: geology, geomorphology, dynamics and human impact. Geological Quarterly 49(4): 355-362.

Blomgren S., Hanson H., 2000. Coastal geomorphology at the Falsterbo Peninsula, southern Sweden. Journal of Coastal Research 16(1): 15-25.

Bobykina V. P., 2007. Peculiarity of morphology and dynamic of marine coast of Northern part of the Vistula Spit (in Russian). In: V. V. Orlionok (ed.), Ecological problems of Kaliningrad oblast and Baltic Region. Kaliningrad: 20-26.

BobykinaV., Karmanov K., Chubarenko B., 2016. Morphodynamics of the shores of the Vistula Spit (the Baltic Sea) in a period of 2002-2015 by results of in-situ measurements. In: Managing risks to coastal regions and communities in a changing world. Proceedings of International Conference EMECS'11-SeaCoasts XXVI, Saint-Petersburg, 22-27 August, 2016, Saint-Petersburg, RSHU.

Boldyrev V.L., Bobykina V., 2008. The coasts of the Vistula and Curonian Spits as transboundary territory. In: B.V. Chubarenko (ed.), Transboundary waters and basins in the South-Eastern Baltic. Terra Baltica, Kaliningrad: 226-238.

Boldyrev V.L., Bobykina V.P., 2001. The general characteristics of the morphology and dynamic of the Vistula Spit (in Russian). In: The ecological problems of the Kaliningrad and Baltic. Kaliningrad: 88-92.

Bontje L.E., Fredriksson C., Wang Z., Slinger J.H., 2016. Coastal erosion and beach nourishment in Scania. As is- 
sues in Swedish coastal policy. Journal of Water Management and Research 72: 103-115.

Borówka R.K., 1990. Coastal dunes in Poland. In: Th.W. Bakker, P.D. Jungerius, J.A. Klijn (eds.), Dunes of the European coasts. Catena Supplement 18: 25-30.

Borówka R.K., 2001. Morfologia i dynamika Wydm Łebskich. In: K. Rotnicki (ed.), Przemiany środowiska geograficznego nizin nadmorskich potudniowego Battyku w vistulianie i holocenie. Bogucki Wydawnictwo Naukowe, Poznań: 85-87.

Burnashov E.M., Karmanov K.V. 2016. Deflation processes on the sea coast of the Curonian Spit (in Russian). Journal of Russian State Hydrometeorological University 45: 180-191.

Česnulevičius A., Izmaiłow B., Morkūnaitė R., 2006. Dynamics of deflation hollows of the Main Ridge in the Curonian Spit. Geografija 42(2): 21-28.

Česnulevičius A., Morkūnaitè R., 1998. The some aspects of comparative characteristics of the old and new generation dunes in the Curonian spit. The Geographical Yearbook 31: 199-210.

Česnulevičius A., Morkūnaitè R., Bautrènas A., Bevainis L., Ovodas D., 2017. Intensity of geodynamic processes in the Lithuanian part of the Curonian Spit. Earth System Dynamics 8: 419-428.

Christiansen Ch., Dalsgaard K., Moller J.T.M., Browman D., 1990. Coastal dunes in Denmark: chronology in relation to sea level. In: Th.W. Bakker,P.D. Jungerius, J.A. Klijn, (eds.), Dunes of the European coasts. Catena supplement 18: 61-70.

Clemmensen L.B., Bendixen M., Nielsen L., Jensen S., Schrøder L., 2011. Coastal evolution of a cuspate foreland (Flakket, Anholt, Denmark) between 2006 and 2010. Bulletin of Geological Society of Denmark 59: 37-44.

Clemmensen L.B., Bjørnsen M., Murray A., Pedersen K., 2007. Formation of aeolian dunes on Anholt, Denmark since AD 1560: a record of deforestation and increased storminess. Sedimentary Geology 199 (3-4): 171-187.

Clemmensen L.B., Glad A.C., Hansen K.W.T., Murray A.S., 2015. Episodes of aeolian sand movement on a large spit system (Skagen Odde, Denmark) and North Atlantic storminess during the Little Ice Age. Bulletin of the Geological Society of Denmark 63: 17-28.

Donner J.J., Simola M., 1977. Some ventifacts found near recent and fossil coastal dunes in Finland. Bulletin of Geological Society of Finland 49: 19-23

Eberhards G., 1998. Coastal dunes in Latvia. In: Environmental perspectives of Southeast Baltic coastal areas through time, Field Guide, Riga: 18-25.

Eberhards G., 2003. The sea coast of Latvia: morphology structure, coastal processes, risk zone, forecast, coastal protection and monitoring. Latvijas Universitate, Riga, Latvia.

Eberhards G., Grine I., Lapinskis J., Purgalis I., Saltupe B., Torklere A., 2009. Changes in Latvia's seacoast (19352007). Baltica 22(1): 11-22.

Eberhards G., Saltupe B., 1995. Accelerated coastal erosion-implications for Latvia. Baltica 9: 16-28.

Fedorowicz S., Gołębiewski R., Wysiecka G., 2009. The age of the dunes of the Vistula Spit in the vicinity of Stegna. Geologija 51(3-4): 139-145.

Grunewald R., 2006a. Assessment of damages from recreational activities on coastal dunes of the Southern Baltic Sea. Journal of Coastal Research 22(5): 1145-1157.

Grunewald R., 2006b. Effects of recreational activities on beach and dune vegetation along the Pommeranian Bight. Dissertation Faculty of Natural Sciences. University of Rostock, Germany.
Grunewald R., Schubert H., 2007. The definition of a new plant diversity index "H'dune" for assessing human damage on coastal dunes - derived from the Shannon index of entropy - $\mathrm{H}^{\prime}$. Ecological Indicators. Ecological Indicators 7: 1-21.

Gudelis V., 1998.The Lithuanian offshore and coast of the Baltic Sea. Lithuanian Science, Vilnius: 1-439.

Gudelis V., Michaliukaitė E., 1976. Ancient parabolic dunes of the Kurńių Nerija Spit. Geographia Lituanica: 59-63.

Gurwell B. 2008. Coastal protection along the Baltic Sea coast - Mecklemburg-Vorpommern. In: North Sea and Baltic coast. Die Küste 74, ICCE: 179-188.

Habicht H.-L., Rosentau A., Jõeleht A., Heinsalu A., Kriiska A., Kohv M., Hang T., Aunap R., 2017. GIS-based multiproxy coastline reconstruction of the eastern Gulf of Riga, Baltic Sea, during the Stone Age. Boreas 46: 83-99.

Halldén T., 2017. Measuring coastal erosion along the coast of Ystad municipality using PSInSAR and SBAS. Master's thesis. Physical Geography and Quaternary Geology, Stockholm University, NKA173, Sweden: 1-140.

Hansen K., Vestergaard P., 1986. Initial establishment of vegetation in a man-made coastal area in Denmark. Nordic Journal of Botany 6: 479-495.

Hanson H., 2002. Eurosion case study Ystad, Sweden. EUROSION Study in Europe: 1-14.

Hauerbach P., 1992. Skagen Odde - Skaw Spit. An area of land created between two seas. Folia Geographica Danica 20: $1-119$.

Heikkinen O., Tikanen M., 1987. The Kalajoki dune field on the west coast of Finland. Fenna 165(2): 241-267.

Hellemaa P., 1998. The development of coastal dunes and their vegetation in Finland. Fenna 176, Helsinki: 1-157.

Hoffmann G., 2004. Postglacial to holocene sedimentation history and palaeogeographical development of a barrier spit (Pudagla lowland, Usedom Island, SW Baltic coast). Polish Geological Institute Special Papers 11: 83-90.

Hoffmann G., Lampe R., Barnasch J., 2005. Postglacial evolution of coastal barriers along the West Pomeranian coast, NE Germany. Quaternary International 133-134: 47-59.

Isermann M., Krisch H., 1995. Dunes in contradiction with different interests. An example: The campingground Prerow (Dars/Baltic Sea). In: A.H.P.M. Salman, H.Berends, M. Bonazountas (eds.), Coastal management and habitat conservation. Marathon, Greece: 439-449.

Jarmalavičius D., Žilinskas G., 2006. Peculiarities of sand sorting in the Lithuanian coast of the Baltic Sea. Geologija 56: $36-42$.

Kabailienė M., 1996. Geological structure of the Kuršiu Nerija Spit and Kuršių Marios Lagoon, development during Late Glacial and Holocene. Geological history of the Baltic sea. Vilnius: 1-33.

Kall T., Liibusk A., Wan J., Raamat R., 2016. Vertical crustal movements in Estonia determined from precise levellings and observations of the level of Lake Peipsi. Estonian Journal of Earth Sciences 65: 27-47.

Kobelyanskaya J., Bobykina V.P., Piekarek-Jankowska H., 2011. Morphological and lithodynamic conditions in the marine coastal zone of the Vistula Spit (Gulf of Gdańsk, Baltic Sea). Oceanologia 53(4): 1027-1043.

Kobelyanskaya J., Piekarek-Jankowska, Boldyrev V.L., Bobykina V.P., Stępniewski P. 2009. The morphodynamics of the Vistula Spit seaward coast (Southern Baltic, Poland, Russia). Oceanological and Hydrobiological Studies 38 (Supplement 1): 41-56 
Koltsova T., Belakova J., 2009. Storm Surges on the Southern Coast of Gulf of Riga: Case Study of the Lielupe River. Threats to Global Water Security. NATO Science for Peace and Security, Series C: 91-97.

Kose M., Kose M., Klein A., 2002. The conservation history of the Rannametsa Dunes. Forestry Studies 39: 93-98.

Kosekela K., Sievänen M. (eds.), 2009. Restoration, environmental management and monitoring in the Vattaja dune Life Project 2005-2009. Nature Protection Publications of Mesähallitus. Series A181: 1-40.

Łabuz T. A., Grunewald R., 2007. Studies on vegetation cover of the youngest dunes of the Świna Gate Barrier (West Polish coast). Journal of Coastal Research 23(1): 160-172.

Łabuz T.A., 2005. Dune shores of Polish Baltic coast (in Polish). Czasopismo Geograficzne 76: 19-47.

Łabuz T.A., 2009. The West Pomerania coastal dunes - alert state of their development. Zeitschrift der Deutschen Gesellschaft fur Geowissenschaften 160(2): 113-122.

Łabuz T.A., 2013. Polish coastal dunes - affecting factors and morphology. Landform Analysis 22: 33-59.

Łabuz T.A., 2015a. Coastal dunes: Changes of their perception and environmental management. In: Ch.W. Finkl, Ch. Makowski (eds.), Environmental management and governance. Advances in coastal and marine resources series. Coastal Research Library, Vol. 8, Springer (441p.): 323 410.

Łabuz T.A., 2015b. Environmental impacts - coastal erosion and coastline changes. Chapter 20. In: BACC II Team (eds.), Second assessment of climate change for the Baltic Sea basin.Springer (515p.): 381-396.

Łabuz T.A., 2017. The sandy coasts of Baltic Sea -types and location (in Polish). Abstract of III Symposium of Marine Geomorphology, Gdańsk University, 24.11.2017, Gdańsk (unpublished).

Lampe R., 1996. Küsten und Küstenschutz in Mecklenburg Vorpommern. Erdkundeunterricht 9: 364-372.

Lampe R., 2002. Holocene evolution and coastal dynamics of the Fischland Darss Zingst peninsula. Greifswald Geographische Arbeiten 27(D1): 155-163.

Larson M., Hanson H., 2013. Coastal erosion and protection in Sweden. In: E. Pranzini, A.T. Williams (eds.), Coastal erosion and protection in Europe. Earthscan Ltd, Routledge, Oxon: 31-46.

Lehvo A., Ekebom J., Bäck S., 1998. Introduction to the marine and coastal environment of Finland. Red list of marine and coastal biotopes and biotope complexes of the Baltic Sea, Belt Sea and Kattegat. Baltic Sea Environment Proceedings 75, Helsinki Commission: 23-26.

Miszalski J., 1973. Wspótczesne procesy eoliczne na pobrzeżu stowińskim. Studium fotointerpretacyjne. Dokumentacja Geograficzna 3, IG PAN, Warszawa: 1-150.

Mojski J.E., 1995. Geology and evolution of the Vistula Delta and Vistula Bar. In: K. Rotnicki (ed.), Polish coast past, present and future. Journal of Coastal Research, Special Issue 22: 141-149.

Morkūnaitè R., Bautrènas A., Česnulevičius A., 2017. The recent investigations and providences about active aeolian forms in Curonian Spit (Lithuania). Acta Geographica Silesiana 11/1(25): 23-29.

Morkūnaitè R., Česnulevičius A., 2005. Changes in blowout segments of the Main Ridge in the Curonian Spit in 1999_ 2003. Acta Zoologica Lituanica 15(2): 145-150.

Orviku K., Jaagus J., Kont A., Ratas U., Rivis R., 2003. Increasing activity of coastal processes associated with climate change in Estonia. Journal of Coastal Research 19: 364-375.
Orviku K., Romm G., 1992. Litho-morphodynamical processes of Narva Bay (in Russian). Proceedings of the Estonian Academy of Sciences. Geology 41(3): 138-147.

Piotrowska H., Gos K., 1995. Coastal dune vegetation in Poland: diversity and development. In: H.W.J. van Dijk (ed.), Management and Preservation of Coastal Habitats. Proceedings of a Multidisciplinary Workshop in Jastęrzbia Góra, September 1-5, 1993: 71-82.

Piotrowski A., 1999. Etapy rozwoju Bramy Świny. In: R.K. Borówka, A. Piotrowski, Z. Wiśniowski (eds.), Problemy geologii, hydrogeologii i ochrony środowiska wybrzeża morskiego Zachodniego Pomorza. Przewodnik LXX Zjazdu Naukowego PTG, Szczecin: 215-241.

Povilanskas R., 2002. Eurosion in Gulf of Riga, Latvia, EUROSION Study. EUCC Baltic Office: 1-17.

Povilanskas R., 2009. Spatial diversity of modern geomorphological processes on a Holocene Dune Ridge on the Curonian Spit in the South-East Baltic. Baltica 22(2): 77-88.

Pruszak Z., Zawadzka E., 2008. Potential implications of sea level rise for Poland. Jorunal of Coastal Research 24: 410422.

Racinowski R., Seul C., 1996. Actual morphodynamic attributes of Szczecin shore. In: Z. Meyer (ed.), Lithodynamics of sea shore. PAS, Technical University of Szczecin, Szczecin: 107-116.

Ratas U., Rivis R., 2003. Coastal dune landscapes of Estonia. In: M. Mandre (ed.), Forestry Studies XXXIX: 9-19.

Ratas U., Rivis R., Käärt K., 2008. Changes of coastal dune landscapes in Estonia. Forestry Studies 49: 59-70.

Ratas U., Rivis R., Truus L., Vilumaa K., Multer L., Anderson A., 2011. The aeolian coastal ecosystems of Estonia and their changes. Journal of Coastal Research, Special Issue 64: 430-433.

Rosa B., 1963. O rozwoju morfologicznym wybrzeża Polski w swietle dawnych form brzegowych. Studia Societatis Scientarum Torunensis, vol. V, Toruń: 1-172.

Rosentau A., Jõeleht A., Plado J., Aunap R., Muru M., Eskola K.O., 2013. Development of the Holocene foredune plain in the Narva-Joesuu area, eastern Gulf of Finland. Geological Quarterly 57(1): 89-100.

Rotnicki K., Borówka R.K., 1995. Shoreline changes of the Łeba barrier in modern times. In: K. Rotnicki (ed.), Polish coast: past, present, future. Journal of Coastal Research, Special Issue 22: 271-274.

Rucińska-Zjadacz M., Rudowski S., Wróblewski R., 2009. Geneza, stan i rozwój barier piaszczystych Zatoki Puckiej. In: A. Kostrzewski, R. Paluszkiewicz (eds.), Geneza, litologia i stratygrafia utworów czwartorzędowych 5, Poznań: 493-504.

Ryabchuk D., Leontyev I., Sergeev A., Nesterova E., Sukhacheva L., Zhamoida V., 2011. The morphology of sand spits and the genesis of long-shore sand waves on the coast of the eastern Gulf of Finland. Baltica 24: 3-24.

Ryabchuk D., Sukhacheva L., Spiridonov M., Zhamoida V., Kurennoy D., 2009. Coastal processes in the eastern Gulf of Finland - Possible driving forces and the connection with nearshore development. Estonian Journal of Engineering 15: 151-167.

Schumacher W., 2002a. Coastal dynamics and coastal protection of the Island of Usedom. Greifswalder Geographische Arbeiten C 27/C 8, Greifswald: 131-134.

Schumacher W., 2002b. Coastal evolution of the Darss Peninsula. Greifswalder Geographische Arbeiten C27/D2: 165-168. 
Schwartz M.L., Granö O., Pyökäri M., 1989. Spits and tombolos in the southwest archipelago of Finland. Journal of Coastal Research 5: 443-451.

Seppälä M., 1995. Deflation and redeposition of sand dunes in Finnish Lapland. Quaternary Science Reviews 14(7-8): 799-809.

Soomere T., Viška M., Lapinskis J., Räämet A., 2011. Linking wave loads with the intensity of erosion along the coasts of Latvia. Estonian Journal of Engineering 17: 359-374.

Suursaar Ü., Jaagus J., Kont A., Rivis R., Tõnisson H., 2008. Field observations on hydrodynamics and coastal geomorphic processes of Harilaid Peninsula (Baltic Sea) in winter and spring 2006-2007. Estuarine Coastal and Shelf Sciences 80: 31-41.

Suursaar Ü., Tõnisson H., 2017. Storminess-related rhythmic ridge patterns on the coasts of Estonia. Estonian Journal of Earth Sciences 66(4): in print.

Tolvanen H., Numminen S., Kalliola R., 2004. Spatial distribution and dynamics of special shore-forms (tombolos, flats and glo-lakes) in an uplifting archipelago of the Baltic Sea. Journal of Coastal Research 20(1): 234-243.

Tomczak A., 1995a. Geological structure and Holocene evolution of the Polish coastal zone. Publications of Polish Geological Institute 149: 90-102.

Tomczak A., 1995b. Relief, geology and evolution of the Hel Spit. In: K. Rotnicki (ed.), Polish coast: past, present, future. Journal of Coastal Research, Special Issue 22: 181-185.

Tõnisson H., Orviku K., Jaagus J., Suursaar Ü., Kont A., Rivis R., 2008. Coastal damages on Saaremaa Island, Estonia, caused by the extreme storm and flooding on January 9, 2005. Journal of Coastal Research 24: 602-614.
Tõnisson H., Suursaar Ü., Rivis, R., Kont A., Orviku K., 2013. Observation and analysis of coastal changes in the West Estonian Archipelago caused by storm Ulli (Emil) in January 2012. Journal of Coastal Research, Special Issue 65: 832-837.

Vilumaa K., Tõnisson H., Sugita S., Buynevich I.V., Kont A., Muru M., Preusser F., Bjursäter S., Vaasma T., Vandel E., Molodkov A., Järvelill J.I., 2016. Past extreme events recorded in the internal architecture of coastal formations in the Baltic Sea region. Journal of Coastal Research, Special Issue 75: 775-779.

Žaromskis R., Gulbinskas S., 2010. Main patterns of coastal zone development of the Curonian Spit, Lithuania. Baltica 23(2): 149-156.

Zawadzka-Kahlau E., 1999. Tendencje rozwojowe polskich brzegów Battyku Potudniowego. IBW PAN, Gdańsk: 1-149.

Zawadzka-Kahlau E., 2012. Morfodynamika brzegów wydmowych potudniowego Battyku. Wydawnictwo Uniwersytetu Gdańskiego, Gdańsk: 1-353.

Zhamoida V.A., Ryabchuk D.V., Kropatchev Y.P., Kurennoy D., Boldyrev V.L., Sivkov V.V., 2009. Recent sedimentation processes in the coastal zone of the Curonian Spit (Kaliningrad region, Baltic Sea). Zeitschrift für Geomorphologie 160(2): 143-157.

Žilinskas G., Jarmalavičius D., 1997. Morphometric characteristics of the Lithuanian coasts of the Baltic Sea. Geography 33: $64-71$.

Žilinskas G., Jarmalavičius D., 2003. Trends of Lithuanian sea coast dynamics. The Geographical Yearbook 36(1): 80-88.

Žilinskas G., 2005. Trends in dynamic processes along the Lithuanian Baltic coast. Acta Zoologica Lituanica 15(2): 204-207. 